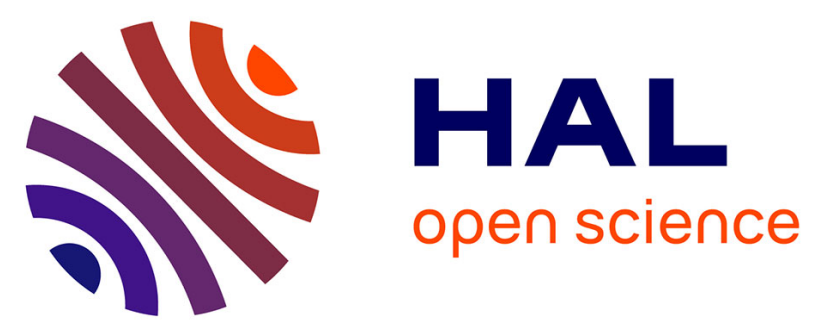

\title{
Stratigraphic comparisons along the Pontides (Turkey) based on new nannoplankton age determinations in the Eastern Pontides: geodynamic implications
} Jean-Claude Hippolyte, C. Müller, E. Sangu, N. Kaymakci

\section{- To cite this version:}

Jean-Claude Hippolyte, C. Müller, E. Sangu, N. Kaymakci. Stratigraphic comparisons along the Pontides (Turkey) based on new nannoplankton age determinations in the Eastern Pontides: geodynamic implications. The Geological Society, London, Special Publications, 2017, Tectonic Evolution of the Eastern Black Sea and Caucasus., 428 (1), pp.323 - 358. 10.1144/SP428.9 . hal-01708711

\author{
HAL Id: hal-01708711 \\ https://hal.science/hal-01708711
}

Submitted on 14 Feb 2018

HAL is a multi-disciplinary open access archive for the deposit and dissemination of scientific research documents, whether they are published or not. The documents may come from teaching and research institutions in France or abroad, or from public or private research centers.
L'archive ouverte pluridisciplinaire HAL, est destinée au dépôt et à la diffusion de documents scientifiques de niveau recherche, publiés ou non, émanant des établissements d'enseignement et de recherche français ou étrangers, des laboratoires publics ou privés. 
Stratigraphic comparisons along the Pontides (Turkey) based on new nannoplankton age determinations in the Eastern Pontides: geodynamic implications

\section{J-C. Hippolyte, C. Müller, E. Sangu and N. Kaymakci}

Hippolyte Jean-Claude *

UMR-6635 CNRS - Universite Aix-Marseille III

BP 80, Europole Mediterraneen de l'Arbois

13545 Aix en Provence Cedex 4, FRANCE

Tel. +334 429717 70, Fax. +334429716 58, e-mail: hippolyte@cerege.fr

Müller Carla

PL-66-431b Santok, Ludzislawice 36, Poland

Sangu Ercan

Kocaeli University, Department of Geological Engineering, 41100 Kocaeli, Turkey

Kaymakci Nuretdın

Middle East Technical University, Department of Geological Engineering, 06800Ankara Turkey.

* Corresponding author:

9945 words (abstract to Acknowledgement)

92 references

15 figures

1 table

Abbreviated title: Stratigraphic comparisons along Pontides 


\begin{abstract}
We compared the stratigraphic formations along the southern margin of the Black Sea using 196 nannoplankton ages determined in the Western and Central Pontides, and 112 new samples from the Eastern Pontides. We inferred that the İstanbul and Sakarya zones were amalgamated prior to the Early Cretaceous. Extensional subsidence migrated eastwards along the Pontides from the Barremian to the Palaeocene. An eastwards younging of the Cretaceous magmatism suggested that the eastern Black Sea Basin is younger. Locally, angular unconformities and a stratigraphic gap testify to the Late Albian uplift of the Central Pontides, as the consequence of the collision of an oceanic edifice. Cretaceous Oceanic Red Beds are marker beds of Santonian age along the much of the Pontides, and are of mainly Campanian age within the Eastern Pontides. The Middle-Campanian-Paleocene was a non-volcanic period characterized by extensional subsidence mainly along the eastern Black Sea Basin. The end of Cretaceous volcanism can be correlated with a southwards subduction jump. Syn-compressional basins show that contraction started during the Ypresian along the entire Pontide belt. Eocene volcanism started earlier in the north (Lutetian) than in the south (Bartonian) of the Eastern Pontides. This propagation of syn-collisional volcanism could have resulted from slab steepening under the Eastern Pontides.
\end{abstract}

Keywords: Pontides, Black Sea, nannoplankton, stratigraphy, geodynamics, rifting, volcanic arc

The Pontides is a mountain belt in northern Anatolia that extends over more than $1000 \mathrm{~km}$ along the southern margin of the Black Sea Basin (Fig. 1). The North Anatolian Fault runs along the length of this range. The Pontide domain was located at the southern margin of Laurasia and recorded extensional and compressional events related to the northwards subduction of the Tethys Ocean since at least the Triassic (Barrier and Vrielynck, 2008). These events include the opening of the Black Sea back-arc basin, and the collision of continental fragments derived from Gondwana during the Mesozoic (Kırşehir block, Tauride-Anatolide block, Arabian plate) (Hsü et al. 1977; Letouzey et al. 1977; Şengör \& Y1lmaz 1981; Zonenshain \& Le Pichon 1986; Y1lmaz et al. 1997; Okay \& Tüysüz, 1999; Yiğitbaş et al., 1999; Kaymakc1 et al. 2000, 2009, 2010, Ustaömer \& Robertson 2010; Robertson et al. 2014; Nikishin et al. 2015a). Compressional events and extensional episodes might have been diachronous along this long east-west striking mountain belt. The Cretaceous to Paleocene Black Sea back-arc basin is composed of two main sub-basins of either different ages (e.g. Robinson et al. 1996), or of same age (Nikishin et al. 2015a) separated by the Mid-Black Sea High (e.g. Finetti et al. 1988; Görür 1988; Manetti et al. 1988; Robinson et al. 1995; Yegorova et al. 2013; Graham et al. 2013, Nikishin et al. 2015b). As a result of the lack of direct data from the thick sedimentary infill, the interpretation of seismic lines within the Black Sea Basin is mainly based on correlations with onshore data (e.g. Finetti et al. 1988; Robinson et al. 1996; Graham et al. 2013; Nikishin et al. 2015b). A knowledge of the stratigraphic evolution of the Pontides, that reflects the geodynamic evolution of these basins and of crustal blocks, is therefore of fundamental importance. Accurate stratigraphic ages of the rock formations of the Pontides and their correlation along the entire belt may provide a better understanding of the geologic evolution of this complex area. 
A previous revision of the age of rock formations based on nannoplankton fossil assemblages from 164 samples, suggested strong similarities between the Western Pontides and the western part of the Central Pontides (Fig. 1; Hippolyte et al. 2010). It also revealed a stratigraphic gap locally extending from the Upper Albian to the Turonian, which was interpreted to be the result either of rift shoulder uplift during the Black Sea opening, or of collisions along the Tethyan subduction zone (Hippolyte et al. 2010; Meijers et al. 2010, Okay et al. 2013). Thirty-two other nannoplankton age determinations in the Sinop-Boyabat area (Espurt et al. 2014; Hippolyte et al., 2015) confirm the similarities in the Cretaceous to Recent stratigraphic sequences between the Western Pontides and the Central Pontides separated by the "Araç-Daday Shear Zone" (Fig. 1; e.g. Y1lmaz al. 1997).

We present and discuss here 112 new nannoplankton ages determined by $\mathrm{C}$. Müller from 174 rock samples at 109 sites within the Eastern Pontides (Table 1). Comparisons with the stratigraphic series of the Central and Western Pontides revealed similarities and differences that we relate to the opening of the Black Sea Basin and to the evolution of the Tethyan subduction zone. We focus on the Late Jurassic to Recent period and do not discuss the older (Paleotethyan) evolution that has been debated elsewhere (e.g. Şengör \& Y1lmaz 1981; Yiğitbaş et al. 1999; Ustaömer \& Robertson 2010).

\section{Geological setting:}

The Pontide mountain belt borders the Black Sea Basin to the south and probably results from the tectonic inversion of its southern margin (e.g. Hippolyte et al. 2010; Espurt et al. 2014). Rifting of the western Black Sea Basin is often considered to have started during the Early to Middle Cretaceous (Late Barremian or Aptian-Albian-Cenomanian; e.g. Finetti et al. 1988; Görür 1988; Manetti et al. 1988; Görür et al. 1993; Robinson et al. 1996; Hippolyte et al., 2010). This age is mainly supported by facies and thickness variations within the Cretaceous stratigraphic sequences of the Western Pontides (Görür 1988, 1997; Görür et al. 1993). Other researchers have suggested that it opened contemporaneously with the volcanic activity, from the Turonian to Maastrichtian (Tüysüz 1999; Tüysüz et al. 2012). There is no consensus on the age of the eastern Black Sea Basin. It is supposed to have rifted either during the Albian to Santonian (Bektas et al. 1995; Eren \& Tasli 2002) or during the Late Paleocene (Robinson et al. 1995; Robinson 1997). This post-Danian age of rifting is supported by the presence of an almost complete Mesozoic to Lower Palaeocene series within exploration wells drilled on the Shatsky Ridge (e.g. Robinson et al. 1996).

Likewise, even if the Pontide mountain belt looks like a continuous eastwest-trending structure, its stratigraphic sequence is generally thought to change along strike. The Araç-Daday Shear Zone (Fig. 1), considered to be the eastern continuation of the Intra-Pontide suture (Y1lmaz et al., 1997; Tüysüz 1999; Okay \& Tüysüz 1999) is traditionally taken as the limit between the Western Pontides and the Central Pontides (e.g. Y1lmaz et al. 1997; Tüysüz et al. 2012). Below a Jurassic to Eocene sedimentary cover, the basement of the Western Pontides, called İstanbul Zone, is characterized by a non-metamorphosed Palaeozoic (Ordovician to Carboniferous) sedimentary sequence, which contrasts with the basement of the Central and Eastern Pontides, called Sakarya Zone (e.g. Şengör \& Y1lmaz 1981; Okay et al. 1994; Yılmaz et al. 1997; Elmas \& Yiğitbaş 2001). There is no agreement about the age of juxtaposition of the Sakarya and İstanbul zones. Depending on whether the researchers point out similarities or differences in the Lower Cretaceous stratigraphic sequences, the juxtaposition of these two zones is considered to have occurred after the Middle Paleocene (Okay et al. 1994) or 
during the Late Cretaceous (Yiğitbaş et al. 1999), during the Albian-Cenomanian (Tüysüz 1999), during the Early Cretaceous (Akbayram et al. 2013), or before the Early Cretaceous (Okay et al. 2013).

The eastern part of the Sakarya Zone is called the Eastern Pontides (Fig. 1).

During the Late Cretaceous a volcanic arc was initiated on the northern margin of Neotethys due to the northward subduction of Neotethyan oceanic crust along the southern border of the Sakarya Zone (e.g. Hsü et al. 1977; Letouzey et al. 1977; Şengör \& Yılmaz 1981; Zonenshain \& Le Pichon 1986; Yilmaz et al. 1997; Yiğitbaş et al. 1999; Şengör et al. 2003). The southeastern margin of the Pontides is characterized by ophiolitic mélange nappes of Cretaceous age (Fig. 1) that form the Eastern Anatolian Accretionary Complex. Their emplacement over the Tauride Platform and back-thrusting over the Eurasian margin backstop occurred during the Late Cretaceous (e.g. Hässig et al., 2014). It was followed by continental collision during Late Palaeocene-Early Eocene times (e.g. Yılmaz et al 1997; Şengör et al. 2003; Rice et al. 2009; Robertson et al. 2014). The Upper Cretaceous-Cenozoic stratigraphy of the Eastern Pontides mainly differs from that of the Central and Western Pontides by the development of large amount of volcanic and plutonic rocks of the Pontide magmatic arc (e.g. Şengör \& Y1lmaz 1981; Okay \& Şahintürk 1997; Okay \& Tüysüz 1999; Ustaömer \& Robertson 2010; Eyuboglu et al. 2013; Hakyemez \& Papak 2002; Aydınçakır \& Şen 2013; Fig. 1). The Upper CretaceousEocene volcanic and volcaniclastic rock series, with alternating carbonate rocks, all cut by intrusions, can be more than $2 \mathrm{~km}$ thick on the northern part of the volcanic arc (Okay \& Şahintürk 1997). Other stratigraphic similarities and differences within the Upper Jurassic to recent stratigraphic series are discussed in this paper.

Note that the term Central Pontides is also used for the arc-shaped central part of the Pontides (e.g. Meijers et al. 2010; Hippolyte et al. 2010; Okay et al. 2013). To avoid confusion, in this paper we will prefer the term Central Pontide Arc (Hippolyte et al. 2010) for this area that extends between Ereğli and Samsun (Fig. 1). We compare the published nannoplankton ages of rock formations of the Central Pontide Arc, with unpublished nannoplankton ages from eight main areas within the Eastern Pontides (Figs 2 and 3; Table 1).

\section{Upper Jurassic and Lower Cretaceous}

During the Late Jurassic, the İstanbul and Sakarya zones evolved into platforms on which were deposited Upper Jurassic-Lower Cretaceous platform carbonates of the İnaltı Formation (Ketin \& Gümüş 1963; Derman \& Sayıl1 1995) and the Berdiga Formation (Pelin 1977) respectively (Fig. 3).

\section{Upper Jurassic and Lower Cretaceous of the Central Pontide Arc}

Upper Jurassic to Lower Cretaceous platform carbonates extensively crop out both within the Central Pontides and within the Western Pontides. In the Western Pontides the İnaltı Formation of Late Jurassic to Early Cretaceous age (Ketin \& Gümüş 1963; Derman \& Sayıl1 1995) has been interpreted to represent the south-facing carbonate platform of the Neotethyan ocean (e.g. Şengör \& Y1lmaz 1981; Robertson \& Dixon 1984; Koçyiğit \& Altıner 2002). During the Early Cretaceous, the sedimentation changed from shelf carbonates to detrital material with the Çağlayan Group (Kilimli, Sapça, Tasmaca Velibey, Cemaler and Ulus formations; Fig. 3).

Near Zonguldak on the Black sea coast (Fig. 1), Masse et al. (2009) suggested that the evolution from an Upper Barremian carbonate platform to an Aptian siliciclastic system was related to flexural downwarping of tectonic origin. We dated 66 samples from the clastic material of the Çağlayan Group (Hippolyte et 
al. 2010). Their ages, from the Late Barremian to the first part of the Late Albian (Hippolyte et al. 2010) agree with the Late Barremian age of the carbonate platform of Masse et al. (2009).

However, the age of the upper formations of the Çağlayan Group is older than the previously proposed Aptian to Early Cenomanian age (e.g. Tokay, 1952; Görür 1997). The Sapça and Tasmaca formations of the Çağlayan Group that were considered to be of Albian and Cenomanian age respectively (Tokay, 1952; Tüysüz, 1999) contained nannoplankton assemblages not younger than the Early Albian. These new age data locally revealed a stratigraphic gap within the Cretaceous sequence (Fig. 3; Hippolyte et. al. 2010). Observation of angular unconformities indicated that this stratigraphic gap partly resulted from erosion (Fig. 4). The uppermost formation of the Çağlayan Group was locally preserved from this erosion. The shallow marine character of this formation, the Cemaller Formation (Yergök et al., 1987), contrasts with the deepening character of the underlying Lower Cretaceous sequence. Its age shows that uplift, which led to erosion and which explains the Mid-Cretaceous angular unconformities, started during the first part of the Late Albian (Hippolyte, et al., 2010). The Mid-Cretaceous stratigraphic hiatus extends in places from the uppermost Albian to the Coniacian (Fig. 3a). However, the Dereköy Formation, a series of volcanic and volcanogenic sediments that we could not date and which, according to Tokay (1952), Tüysüz (1999) and Tüysüz et al. (2012) contains foraminifers of Middle Turonian-Early Santonian age, locally narrows this stratigraphic gap (Figs. 1 and 3a).

Below the Mid-Cretaceous unconformity, the rocks of the Çağlayan Group are characterized by extensional faulting along the Black Sea coast (Hippolyte et al., 2010). This allowed us to interpret the Lower Cretaceous terrigenous deposits cropping out along the Black Sea coast as synrift deposits of the western Black Sea Basin, as first proposed by Görür (1997).

Immediately east of the "Araç Daday Shear Zone" (Fig. 1), the Ulus Formation of the Çağlayan Group crops out near Ağlıköy (Fig. 1) where three samples indicated ages from Hauterivian to Barremian (Hippolyte et al. 2010; Fig. 3a). These ages, which are older than the age of the base of the Çağlayan Group along the Black sea coast, and the observed intence compressional deformation, suggest that in this area the terrigenous sediments of the Çağlayan Group were deposited with onlap on the accretionary wedge of the Tethyan subduction zone, but not within a Black Sea rift basin as is seen near Zonguldak (Hippolyte et al. 2010; Okay et al. 2013).

In the Cretaceous Boyabat Basin, which is also east of the "Araç-Daday Shear Zone", six samples of the siliciclastic turbidites of the Çağlayan Group (Ketin \& Gümüş 1963) indicated Early Cretaceous ages, up to the Late Aptian (Fig. 3; Hippolyte et al. 2015). The fact that the Lower Cretaceous Çağlayan Group was present within the Boyabat Basin located to the east of the "Araç-Daday Shear Zone" seems to confirm that the İstanbul Zone was already welded to the Sakarya Zone during the Early Cretaceous (e.g. Aydın et al. 1986; Bozkurt et al., 2012; Okay et al 2013; Fig. 3a and 3b).

Finally, in the Central Pontides, near Ağlıköy (Hippolyte et al. 2010) and within the Boyabat Basin (Fig. 4), there is a Mid-Cretaceous stratigraphic gap and a related Coniacian-Santonian unconformity similar to those of the Western Pontides (Fig. 3; Hippolyte et al. 2015). The fact that the most recent deposits of the Çağlayan Group were of Aptian age both within the Boyabat Basin and within the Ulus Basin (F. 3a and b; Hippolyte et al. 2010) indicates that the İstanbul and Sakarya zones underwent similar tectonic events during the Cretaceous. Similarities in facies (turbiditic sediments with olistoliths) and ages support the idea that the 
Boyabat flysch basin was a fore-arc basin (Espurt et al. 2014) lateral equivalent of the Ulus flysch basin during the Early Cretaceous (e.g. Okay et al. 2013).

\section{Upper Jurassic and Lower Cretaceous of the Eastern Pontides}

The Upper Jurassic to Lower Cretaceous neritic limestone of the Berdiga Formation (Pelin 1977; Y1lmaz 2002; Eren \& Talis 2002) is age-equivalent of the Inalt1 Formation of the Central Pontides (Fig. 3). On the northern slope of the Eastern Pontides, it is mainly exposed between Giresun and Rize (Akdeniz \& Güven. 2002; Hakyemez \& Papak 2002; Fig. 2). It covers Lower-Middle Jurassic volcanic series and is overlain by Cretaceous, mainly volcanogenic, rocks. This neritic limestone was deposited on a wide carbonate platform open to the SE (e.g. Şengör \& Y1lmaz 1981; Robertson \& Dixon 1984). Indeed, a thick sequence of pelagic limestone with slump intercalations is present between Olur and Erzincan (Figs. 2 and 5). Immediately south of this pelagic sequence, the Izmir-Ankara-Erzincan suture zone shows the ophiolitic rocks of the Tethys Ocean (Fig. 2). We infer that in the Eastern Pontides, in contrast with the Cantral Pontide Arc, the margin of the Tethys Ocean is still represented by Jurassic pelagic limestone exposed between the neritic limestone of the carbonate platform and the ophiolites of to the Tethyan oceanic crust (Fig. 2; e.g. Şengör \& Y1lmaz 1981; Robertson \& Dixon 1984).

At sites W59 and W63, located $35 \mathrm{~km}$ south of Giresun (Fig. 2), the carbonates immediately beneath the Cretaceous volcanogenic sequence showed nannofossils of Barremian age. Near Olur (Fig. 2), three samples of the pelagic limestone showed nannoplankton of Berriasian and Valanginian ages (samples E86, 87, 90, Fig. 5) and six others showed nannoplankton predating the Barremian (samples E77, 79, 85, 109, 110, 111). We infer that the south-facing carbonate platform and margin were built during the Late Jurassic and earliest Cretaceous along the Eastern Pontides.

It is noteworthy that the large basins with terrigenous sediments of Barremian-Albian age of the Central Pontide Arc do not extend into the Eastern Pontides (Fig. 1). In general, the Barremian-Albian period corresponds to a hiatus within the stratigraphy of the Eastern Pontides (Robinson et al. 1995; Okay \& Şahintürk 1997). Eren \& Tasli (2002) showed that near Gümüşhane, a carbonate platform depositional environment prevailed at least up to the Early Aptian (Fig. 6). On the northern slope of the Eastern Pontides, the Upper Jurassic-Lower Cretaceous platform carbonates are directly overlain by a thick series of volcanic and volcaniclastic rocks, of mainly Late Cretaceous age (Fig. 7). It is possible that the lowermost part of the volcanic sequence is locally of Early Cretaceous age. South of Trabzon, near the village of Akarsu, Konak et al. (2009) described a Barremian-Aptian neritic limestone intercalated (olistolith?) within a volcanic sequence overlain by calciturbidites with Aptian forams. This volcanic sequence underlying the Aptian calciturbidites would constitute the earliest record of Cretaceous magmatism in the Eastern Pontides (Konak et al., 2009). Careful observation of the neritic limestone shows that it includes volcanic clasts, which confirms that it is not an olistolith but a limestone deposited on volcanic rocks of probable Early Cretaceous age (Fig. 7).

On the southern slope of the Eastern Pontides, thin black marly sandstones and silts are exposed above Valanginian carbonates near Olur and Uzundere (Fig. 2). Unfortunately we could not date these Cretaceous terrigenous sediments more accurately than post-Valanginian (Fig. 5). Even if according to their facies they might be the equivalent of the formations of the Çağlayan Group, it remains clear that there was no large Lower Cretaceous flysch or rift basin in the Eastern Pontides similar to those in the Central Pontide Arc. 


\section{Red pelagic limestone}

In the Eastern Pontides, the Late Cretaceous is mainly represented by the Kermutdere Formation, which consists of andesites, basalts, rhyodacitic-dacitic lavas, pyroclastic rocks, tuffs, with intercalations of clayey limestones, sandy limestones, and red pelagic limestones (e.g. Sofracioğlu \& Kandemir 2013). To compare this Upper Cretaceous series with the stratigraphic units of the Central Pontide Arc, we will distinguish the carbonate intercalations (Tonya Formation and red pelagic limestone Members) from the volcanogenic sequence.

\section{Red pelagic limestone in the Central Pontide Arc}

Along the Black Sea slope of the Western Pontides, a c. $30 \mathrm{~m}$ thick series of characteristic thinly bedded red to pinkish (hematite rich) pelagic limestone is referred to as the Kapanboğazı Formation (e.g. Görür et al. 1993). This formation is usually exposed at the base of the volcanic-dominated Yemişliçay Formation (Figs. 1 \& 3; Görür 1997). Near Zonguldak, the red pelagic limestone is intercalated within volcanic-dominated series. This intercalation allowed Tüysüz (1999) and Tüysüz et al. (2012) to distinguish the underlying volcanogenic sequence named Dereköy Formation, from the Yemişliçay Formation of Görür (1997). According to Tüysüz et al. (2012) the Dereköy Formation would be the synrift deposits of the western Black Sea Basin.

Görür et al. (1993) and Görür (1997), attribute the drastic change in sedimentation from the dark siliciclastic sediments of the Çağlayan Group to the overlying red pelagic limestone, deposited in a strongly oxic environment of 500$1000 \mathrm{~m}$ water depth, to a rapid widening of the Black Sea rift, the end of anoxia and the start of regional subsidence. Even if Görür (1997) and Tüysüz et al. (2012) disagree about the age of the triggering of the Black Sea rifting (the Çağlayan Group for the former and the Dereköy Formation for the latter) they agree that the Kapanboğazı Formation is the syn-breakup succession, and that its deposition was related to the beginning of oceanic spreading in the western Black Sea Basin (Görür et al. 1993; Görür 1997; Tüysüz et al. 2012).

The view that the deposition of the Kapanboğazı red limestone has a tectonic significance and records the opening of the Black Sea is questionable with respect to its global distribution, which largely exceeds beyond the Black Sea Basin. Hu et al. (2005) compiled the available data on Cretaceous Oceanic Red Beds (CORBs) and pointed out that they are present in a broad geographic belt extending from the Caribbean across the Europe to Asia (the Alps, Carpathians, and Himalaya). CORBs are diachronous but occurred mainly during the Turonian-Campanian. They were deposited at low rates of sedimentation in a variety of environments, from continental slopes to deep oceanic basins. Hu et al. (2005) concluded that CORBs result from a combination of Earth processes, including changes in oceanic circulation and climate.

In the Pontides, the tectonic significance of CORBs is also questionable because, as noticed by Görür et al. (1993) and Tüysüz (1999), beds of red limestone are also locally intercalated at various levels within the Yemişliçay Formation. To better understand the meaning of these typical red limestone beds, the knowledge of their distribution and age is fundamental.

Based on planktonic foram assemblages, a Cenomanian to Campanian age was proposed for the Kapanboğazı Formation in the Western Pontides (Ketin \& Gümüş 1963; Görür et al. 1993; Görür 1997; Tüysüz 1999). Nannoplankton assemblages, from five samples in the Western Pontides constrained its age as Santonian (Fig. 3; Hippolyte et al., 2010). Tüysüz et al. (2012) confirmed the 
homogeneity of this unit, which they named Unaz Formation, over a large area (250 $\mathrm{km})$. Also using nannoplankton assemblages, they concluded a Late Santonian age for this unit in agreement with Hippolyte et al. (2010).

The Kapanboğazı Formation is also present to the east of the Araç-Daday Shear Zone. In the Central Pontides, near Ağlıköy, it unconformably overlies black shales of Hauterivian age. Here also, Hippolyte et al. (2010) dated this typical red limestone of the Santonian. To the north of this location, and $6 \mathrm{~km}$ east of Doğanyurt (Fig. 1), beds of red pelagic limestone intercalated within the volcanogenic sequence also yielded a Santonian age (Hippolyte et al. 2010). Near Boyabat, the Kapanboğazı limestone, which was deposited over a Cretaceous subduction-accretion complex, was also dated as Coniacian-Santonian by nannoplankton assemblages (Okay et al. 2006). In the Sinop Basin, the Kapanboğazı limestone is present at the base of the Upper Cretaceous volcanicdominated sequence (Ugüz et al. 2002). Its Coniacian-Santonian age was confirmed by a study of a stratigraphic section located to the north of Boyabat (Figs. 1, 3 and 4b; Hippolyte et al. 2015).

Finally, even if thin beds of red pelagic limestone may be found locally, a unique 10-30 meter-thick formation of red limestone was mapped throughout the Central Pontide Arc (Yergök et al., 1987; 1989; Ugüz et al., 2002; Hippolyte et al., 2010; Tüysüz et al. 2012). Despite the various names that were given to this formation, its mapping and Santonian age indicated by nannoplankton assemblages confirm that it constitutes a marker horizon throughout the Central Pontide Arc (Hippolyte et al. 2010; Tüysüz et al. 2012).

\section{Red pelagic limestone in the Eastern Pontides}

In the Eastern Pontides, "Upper Cretaceous pelagic limestone" similar to the Kapanboğazı red pelagic limestone (e.g. Görür et al. 1993) have been reported in the Samsun quadrangle of the 1/500 000 scale geological maps of Turkey, along the North Anatolian Fault (near Alucra, at sites W140 and W159; Fig. 2) (Hakyemez \& Papak 2002). As in the Central Pontide Arc, they are at the base of the Upper Cretaceous volcanic-dominated sequence, and over the Jurassic-lower Cretaceous neritic limestone. Unfortunately, in this area our samples did not allow us to date these red limestone beds more accurately than the Late Cretaceous. However, immediately east of Gümüşhane, Eren \& Tasli (2002) described transgressive red pelagic limestones and red marls in a same stratigraphic position. These sediments are exposed at the base of the Senonian siliciclastic turbidites (Kermutdere Formation; Tokel 1972) and above the Jurassic-Lower Cretaceous neritic limestone of the Berdiga Formation. These researchers related the occurrence of these red beds and of an underlying hardground surface to the breaking up of the Eastern Pontide carbonate platform. Using foram assemblages, they dated the beds of red limestone of the Latest Coniacian to Campanian (Fig. 6). In agreement with this age, we found nannoplankton assemblages of Early Campanian age within sample S93 from the red marls (Fig. 2).

We found typical beds of red pelagic limestone intercalated within the Upper Cretaceous volcanogenic sequence at six sites on the northern slope of the Eastern Pontides (Fig. 2). In particular, $17 \mathrm{~km}$ south of Trabzon a road cut exposure showed two $1 \mathrm{~m}$ thick intercalations of red limestone within the Upper Cretaceous volcanogenic sequence. Samples E2, 3 and E4 yielded nannoplankton assemblages of Late Santonian age (Fig. 2).

However, intercalations of red pelagic limestone were also found within the Campanian volcanogenic sequence. This is illustrated by the Çalkoy section (Fig. 8 ), in which two members of red limestone were recognized within the 
volcanogenic rocks of the Düzköy Formation attributed to the CampanianMaastrichtian (Korkmaz 1993). The upper member is a $>15 \mathrm{~m}$ thick red limestone with thin intercalations of volcaniclastic sediments. Samples from its base yielded nannoplankton assemblages of Early Campanian age (samples W24 and W25; Fig. 8). Another site (sample W30), located $33 \mathrm{~km}$ west of samples W24, showed beds of red pelagic limestone of Late Campanian age, which suggests that the upper part of the thick red limestone sequence of Çalkoy is of the same age (Fig. 8).

The lower member of red pelagic limestone within the Çalkoy section is exposed $80 \mathrm{~m}$ below, intercalated between two layers of white volcanic tuff (Fig. 8). An accurate determination of its age was not possible. It might be equivalent to the Upper Santonian red limestone identified at site E2 (Fig. 2).

Beds of red pelagic limestone intercalated within volcaniclastic sandstones are particularly well exposed at sites W32 and W33 (Fig. 2), located near Dogankent, where they form a $40 \mathrm{~m}$ thick sequence. At site W33, the limestone sequence includes a few intercalations of volcaniclastic sandstones, and contains slumped layers and probable radiolarian cherts (Fig. 9 a-c). Similar characteristics were found $55 \mathrm{~km}$ to the east, near the mountain village of Bektas at $2050 \mathrm{~m}$ elevation (sites of samples W67-70; Fig. 2). At site W67, a member of typical beds of red pelagic limestone contained intercalations of volcaniclastic sandstone (Fig. 9d), probable radiolarian chert (Fig. 9g), and slumped layers (Fig. 9e) with mud balls of red limestone and volcanic clasts within the matrix (Fig. 9h). Samples W67 -W69 were barren of nannofossils, and sample W70 did not yield ages more accurate than Late Cretaceous. However, the stratigraphic position of these red beds within the lower part of the volcanogenic sequence suggests that they are equivalent to the Santonian red limestone of site E2 (Figs. $2 \&$ 7). Note also that, in the ÜnyeOrdu area (Fig. 2), thin beds of red clays of Late Campanian age (sample W79) could also be the equivalent of the Upper Campanian red pelagic limestone.

Hence, in the Eastern Pontides, beds of red pelagic limestone were deposited during the Late Santonian, the Early Campanian and the Late Campanian. We infer that the Kapanboğazı Formation, composed of Santonian red pelagic limestone, is present throughout the Pontides, both in the İstanbul Zone and in the Sakarya Zone, and both on the Black Sea side of the belt and on its Tethyan side. Its geodynamic meaning for the opening of the Black Sea is therefore doubtful. If its deposition was related to the opening of the western Black Sea Basin, why is it present in the Sakarya Zone? If it was deposited within the Black Sea Basin, why is it present above the subduction-accretion complexes in the Central Pontides (Okay et al. 2006) or in a fore-arc setting in the Eastern Pontides (sites W140, W159 and S93; Fig. 2)? Moreover, if the occurrence of the Santonian red pelagic limestone is related to the transition from rifting to spreading in the Black Sea Basin, what is the significance of the upper beds of red limestone of Campanian age?

We showed that, on the northern slope of the Eastern Pontides, beds of red pelagic limestone are generally associated to the Upper Cretaceous volcanic and volcaniclastic rocks. This characteristic was also noticed in the Western Pontides where the upper part of the Kapanboğazı Formation contains intercalations of volcaniclastic sediments (e.g. Görür et al 1993). The red pelagic limestone units contain slumped layers, which indicate unstable slopes, probably related to tectonic deformation at time of deposition. In the Central Pontides slumps and thickness variations of the Coniacian-Santonian sequence from $20 \mathrm{~m}$ to about $2000 \mathrm{~m}$ have been interpreted as related to normal faulting based on cross-section analysis (Hippolyte et al. 2015). In the area studied, the slumped layers of red limestone suggest that extensional deformation related to the opening of the Black Sea also 
occurred on the northern margin of the Eastern Pontides during the SantonianCampanian.

Taking into account the geographical extent of the Upper Cretaceous red beds (Figs $1 \& 2$ ) and the finding that their deposition occurred during at least two main periods in the Pontides (Coniacian-Santonian and Campanian), we conclude that the occurrence of CORBs was probably more related to the environmental and chemical conditions than to a geodynamic change from rifting to spreading within the Black Sea Basin. The fact that red pelagic limestones are interbedded within volcaniclastic series indicates that they were deposited during the activity of the Late Cretaceous volcanic arc. This volcanic environment of deposition supports the interpretation that the characteristic red color resulted from a combination of a submarine volcanic source for hematite (Görür et al. 1993) and the climatic conditions (Hu et al. 2005).

\section{Upper Cretaceous volcanic arc}

Upper Cretaceous volcanic arc in the Western and Central Pontides

In the Western and Central Pontides, the Yemişliçay Formation is an up to 1500 meters-thick series of basaltic-andesitic volcaniclastic and volcanic rocks (Görür et al. 1993). Based on forams, a Turonian to Campanian age was proposed for this formation (Aydın et al. 1986; Tüysüz 1990; Görür et al. 1993).

Our samples yielded only Santonian ages, in agreement with the ConiacianSantonian age of the underlying Kapanboğazı Formation and the Early Campanian age of the overlying marls of the Alapl1 Formation near Amasra (Hippolyte et al., 2010). However, we could not date the volcanic rocks of the Yemişliçay Formation that are locally present beneath the Kapanboğazı Formation near Zonguldak (Alan and Aksay, 2002) and $30 \mathrm{~km}$ west of Cide (Baldiran tuffite member of the Kurucaşile Formation; Akyol et al., 1974; Gedik and Aksay, 2002; Fig. 1). Near Zonguldak, forams from limestone intercalations indicate a Middle TuronianConiacian age for these series, which were named the Dereköy Formation by Tüysüz (1999). This age implies that magmatism started during the Middle Turonian in this area of the Western Pontides (Fig. 3a; Tüysüz et al., 2012). However, we noticed that, south of Zonguldak, part of the Yemişliçay Formation, as mapped by Alan and Aksay (2002), was mapped as Cemaller Formation of Cenomanian age by Yergök et al. (1987). We showed that the Cemaller Formation is not of Cenomanian age, but contains nannoplankton assemblages of the first part of the Late Albian and is the most recent terrigenous formation of the Çağlayan Group (Fig. 3a; Hippolyte et al., 2010). Even if the mapping of these formations is controversial, the available data indicate that Cretaceous volcanism probably occurred in the Western Pontides from the Middle Turonian to the Santonian (Fig. 3a).

In the Central Pontides, near Hanönü, the basal and upper part of the Yemişliçay Formation also contain foraminifera characteristic of the ConiacianSantonian (Okay et al. 2006). In the Sinop Range, the Yemişliçay Formation is locally up to $2000 \mathrm{~m}$ thick and nannoplankton assemblages from one sample confirmed its Coniacian-Santonian age, whereas two samples showed that the volcanic activity lasted until the Early Campanian (Fig. 3b; Hippolyte et al. 2015).

\section{Upper Cretaceous volcanic arc in the Eastern Pontides}

The Eastern Pontides orogenic belt is characterized by a thick Cretaceous sequence of volcanic and volcanogenic rocks, in addition to widespread granitic intrusions. For example, the road between Trabzon and the Akarsu village allows the observation of north-dipping volcanic and volcaniclastic series, probably 
thickened by thrust faults, for about $25 \mathrm{~km}$ (Fig. 2). Along this section, the several kilometre thick volcanogenic sequence stratigraphically overlies Upper JurassicLower Cretaceous platform carbonates, which crop out at Akarsu, and is overlain by a series of Campanian white limestone, calcarenite and marl, which crops out 7 km south of Trabzon (Tonya Formation; Fig. 7).

In the Trabzon-Akarsu stratigraphic section, the volcanogenic sequence is mainly of Santonian age (samples E10, 12, E2, 3, 4, E18, Fig. 7). We could not date the lowermost volcaniclastic series that where attributes to the Barremian-Aptian based on foram assemblages (Konak et al 2009). The uppermost volcaniclastic sediments, below the white carbonates of the Tonya Formation, yielded nannoplankton assemblages of Early Campanian age (sample E136, Fig. 7). Close to this area, the Çalkoy stratigraphic section (Fig. 8) showed volcaniclastic and volcanic rocks with red limestone intercalations up to the Late Campanian.

However, Çalkoy is the only place where we found evidence of volcanic activity during the Late Campanian. To the west, in the Ünye-Ordu area, the Late Cretaceous volcanic activity predates the deposition of a series of Lower Campanian limestones and marls (Fig. 10). To the east, the Arakli, Of, and HopaBorçka stratigraphic sections (Figs $11 \& 12$ ) indicate that volcanism stopped during the Early Campanian. In the Hopa-Borçka area, the volcaniclastic sediments also yielded Santonian nannoplankton assemblages (Fig. 12). Sample E32, near the top of the volcaniclastic sequence, indicates a Late Santonian age, whereas $50 \mathrm{~m}$ above, the white limestone of the Tonya Formation yielded Late Campanian nannoplankton assemblages (samples E34 and E36; Fig. 12). The Lower Campanian volcanogenic sequence and red pelagic limestone observed in the Çalkoy and Of areas (Figs. 8 and 11), were not found within the Hopa-Borçka section (Fig. 12). The fact that a part of the sequence is locally missing or reduced suggests that sedimentation was controlled by extensional faulting as proposed for the Central Pontides (Hippolyte et al. 2015).

In conclusion, stratigraphic ages along the Pontides (Fig. 3) indicate that the Cretaceous volcanic arc was active slightly later in the Central and Eastern Pontides (from the Santonian to Campanian), than in the Western Pontides (from the MiddleTuronian (Tüysüz 1999) to the Santonian (Hippolyte et al., 2010)). The Cretaceous volcanic activity stopped during the Early Campanian in much of the Central and Eastern Pontides (Fig. 3c), but lasted until the start of the Late Campanian in the central part of the Eastern Pontides (Çalkoy stratigraphic section; Fig. 8).

\section{Upper Cretaceous-Palaeocene post-volcanic sequence}

An upper Cretaceous non-volcanic sequence is present all along the Pontides belt. It mainly consists of white carbonates, carbonaceous sandstones and turbiditic sediments. In the Central Pontide Arc, this carbonaceous sequence, named the Akveren Formation, is transgressive over older formations. In the Eastern Pontides, a similar formation of white carbonates, the Tonya Formation, represents the uppermost part of the Mesozoic sequence (e.g. Sofracioğlu \& Kandemir 2013).

\section{Upper Cretaceous-Paleocene post-volcanic sequence in the Central Pontide Arc}

Along the northern slope of the Western Pontides the Yemişliçay Formation is overlain by a non-volcanogenic transgressive sequence, which consists of carbonates and calciturbidites of the Akveren Formation and variegate mudstones (black to reddish) of the Atbaşı Formation (e.g. Ketin and Gümüş 1963; Yiğitbaş et al. 1999, Leren 2003). The foram assemblages indicate that the Akveren Formation is of Maastrichtian age and the Atbaşı Formation is of Palaeocene age (Görür 1997; Tüysüz 1999). Nannoplankton assemblages indicated a Campanian to Palaeocene 
age for this post-volcanic sequence (Alapl, Akveren and Atbaş1 formations) in agreement with the nannoplankton age of the Yemişliçay Formation (Hippolyte et al. 2010; Fig. 3a). In detail, samples from the carbonates of the Akveren Formation yielded Late Campanian to Maastrichtian ages and samples from the underlying marls (Alaplı Formation) yielded Early Campanian ages.

The Central Pontide area is characterized by thick siliciclastic turbidites of the Gürsökü Formation intercalated between the Yemişliçay and the Akveren formations (Fig. 3b). These deposits represent a deep marine turbiditic system that was supplied with siliciclastic sediments from the southwestern margin of the Late Cretaceous Sinop-Boyabat Basin (Leren 2003; Fig. 1). A Campanian-Maastrichtian age was given to the Gürsökü Formation (Ketin \& Gümüş 1963; Tüysüz 1999; Leren 2003). Nannoplankton assemblages yielded Early Campanian to Early Maastrichtian ages for this formation (Hippolyte et al., 2015). In the AğliköyDevrekani basin of the Central Pontides (Fig. 1), we dated a local formation of dark sandstones, the Caylak Formation (Akat et al., 1990), to the Early CampanianMaastrichtian (Hippolyte et al. 2010). These ages demonstrate that the clastic sedimentary rocks of the Gürsökü and Caylak formations are lateral equivalent to the Alapl 1 and Akveren formations of the Western Pontides (Fig. 3).

In the Central Pontides, after the formation of the Gürsökü turbidite submarine fan, the calciturbidites of the Akveren Formation mark the development of carbonate slope-apron systems that evolved to carbonate ramp and reefal platform (Ketin \& Gümüş 1963; Leren 2003). Nannoplankton fauna indicate a Late Maastrichtian to Late Palaeocene age for the Akveren Formation, which constrains the age of the overlying Atbaşi marls to the Late Palaeocene-Eocene (Fig. 3b; Hippolyte et al. 2015).

\section{Upper Cretaceous-Palaeocene post-volcanic sequence in the Eastern Pontides}

In the Eastern Pontides the Upper Cretaceous post-volcanic sequence is well exposed between Ünye and Ordu, and in the Ardanuç basin (Fig. 2, 13 \& 14). Our mapping of the Ünye and Ordu area shows that this mainly carbonaceous sequence lies within graben structures formed on the thick Santonian-Campanian volcanogenic substrate (Fig. 13). It is notable that these NE-trending graben structures are mainly located at the southern prolongation of the Mid-Black Sea High (Fig. 15). Stratigraphic study of their infill is of particular interest because these graben structures might be the southern equivalent of the block faulting revealed by seismic lines within the Mid Black Sea High and ascribed to a Palaeocene extensional event (Robinson et al. 1996).

In the Ünye-Ordu area, the carbonaceous sequence is frequently 200 to 300 $\mathrm{m}$ thick. The location of the samples is given in Figure 13 and a synthetic stratigraphic log for the Ünye-Ordu area is given in figure 10. The oldest deposits of the graben infill are of Early Campanian age, whereas the youngest are of Late Palaeocene age. This mainly carbonaceous sequence is characterized by submarine debris flow deposits intercalated between beds of limestone, carbonaceous sandstone, sandstone and claystone (Fig. 10). The debris-flow deposits are mainly composed of clasts (pebbles and boulders) of basaltic and rhyolitic volcanic rocks from the Upper Cretaceous volcanic substrate, but do not indicate a contemporaneous volcanic activity. Debris flow intercalations within a carbonate sequence can occur in rift basins as the result of the erosion of the bounding fault scarps such as in the Oligocene graben structures of southern France (Hippolyte et al. 1991). In the Ünye-Ordu area, the observation of normal faults confirms this extensional tectonic setting (Fig. 10j). Syndepositional tectonic deformation is also attested by large olistoliths of lava along bounding faults (Fig. 10h). Although no 
volcanic activity was recorded during the Campanian and the Maastrichtian, volcanogenic rocks appear locally within the Paleocene sequence (sample W78). The main Cenozoic volcanic activity is, however, represented by volcanoes that postdate the basin infill and are probably of Eocene to Pliocene age (Terlemez \& Y1lmaz 1980; Fig. 10a).

The Upper Cretaceous carbonaceous sequence is also exposed near Trabzon where the thickness of the Tonya Formation varies between 90 and $260 \mathrm{~m}$ (Sofracioğlu \& Kandemir 2013). On the Akarsu-Trabzon section the Tonya Formation is represented by calciturbidites which consist of an alternation of white calcarenites, marls and mudstones with inoceramids (Fig. 7). Facies architecture studies show that these calciclastic sediments were deposited in a submarine fan system (slope environment) sourced from coeval carbonate platform lying to the east or southeast (Sofracioğlu \& Kandemir 2013). This sequence, which is devoid of volcaniclastic sediments, shows nannoplankton assemblages of Late Campanian age (samples E15 and E16), in agreement with previous age determinations based on planktonic forams (Özer et al. 2008).

The Arakli section, located $25 \mathrm{~km}$ east of Trabzon (Figs $2 \& 11$ ), includes an about $50 \mathrm{~m}$ thick sequence of Upper Cretaceous white neritic carbonates. Its basal shallow water limestone, which contains oysters and corals, overlies volcanic aggregates and is of Early Campanian age (samples S18 and S19; Fig. 11). It is overlain by a series of limestones and calcarenites of Late Campanian age (sample S4, S8 and S9), Middle Maastrichtian age (samples S3, S5 and S20) and Late Maastrichtian age (samples S6 and S11). As in the Ünye-Ordu area, this Lower Campanian-Upper Maastrichtian carbonate sequence does not show any evidence of contemporaneous volcanic activity. The youngest Cretaceous volcaniclastic rocks are dated as Early Campanian in a road cut located $14 \mathrm{~km}$ to the SE of Of city (samples S36 and S39; Fig. 11).

To the SW of Trabzon, within the Çalkoy section, the Tonya Formation consists of about $100 \mathrm{~m}$ of white limestone overlying $10 \mathrm{~m}$ of marls and overlain by $20 \mathrm{~m}$ of dark calcareous sandstones (Fig. 8). Foram assemblages indicate a Maastrichtian-Danian (Korkmaz 1993) or Maastrichtian-Thanetian (İnan et al. 1999) age for this formation. We found that its lower part was still of Late Campanian age (samples W3, W4, W5, W6, W7 and W19; Fig. 8). Its upper part (dark calcareous sandstones) yielded nannoplankton assemblages of the Middle Palaeocene (zone NP5, samples W14, W15 and W16), in agreement with a previous study of this section (Inan et al. 1999). The Tonya Formation is disconformably overlain by a thick volcanogenic sequence (Foldere Formation) of Lutetian age (Korkmaz 1993). Even if there are no debris flow intercalations within the carbonate sequence at this location, the observation of normal faults suggests an extensional tectonic setting during the Late Campanian-Paleocene (Fig. 8).

In the Hopa-Borçka area (Fig. 2), the Upper Cretaceous carbonates constitute a c. $200 \mathrm{~m}$ thick sedimentary pile well exposed $8 \mathrm{~km}$ to the east of Hopa. This section is characterized by well-bedded white limestone, calcarenite and marly limestone, with slumped layers at various levels. Our samples yielded Upper Campanian nannoplankton assemblages at the base of the Tonya limestone (Samples E34 and E36; Fig. 12). A reddish colour appears in the uppermost limestone layers, which are overlain by $>30 \mathrm{~m}$ of marine dark red marls (Fig. 12). These marls yielded Late Maastrichtian and Early Palaeocene nannoplankton assemblages (samples E40, E41 and E42 of the NP2 and NP6 zones; Fig. 12). The Campanian-Paleocene sequence is cut by volcanic dykes and sills, but no volcaniclastic or volcanic rocks were found to be stratigraphically intercalated. This shows that the volcanic activity post-dates the Early Paleocene in this area. This 
inference is compatible with the ${ }^{40} \mathrm{Ar}-{ }^{39} \mathrm{Ar}$ ages of the hornblendes of the overlying volcanic rocks near Borçka, which indicate Middle Eocene (from 46.9 \pm 0.1 to 39.9 $\pm 0.5 \mathrm{Ma}$ ) volcanic activity (Aydınçakır \& Şen 2013). Similar to the Ordu and Çalkoy areas, in the Hopa-Borçka area the Campanian-Paleocene sequence is cut by normal faults, which suggests that sedimentation was controlled by extensional deformation (Fig. 12).

On the southern slope of the belt, the thick marly sequence of the Ardanuç Basin yielded nannoplankton assemblages of Middle Palaeocene to Earliest Eocene age (zones NP6 to NP9, samples E48, E51, E55, E57-E66, E64-E66 and E70; Fig. 14). This indicates that, in this area, the Palaeocene period was also without volcanism (Fig. 14). In fact, an isolated small outcrop of Maastrichtian-Paleocene volcanic rocks (plagioleucitites), which represent the youngest magmatic products related to the north-vergent subduction of the northern branch of Neotethys was identified to the SE of Bayburt, far from the studied sections (Altherr et al., 2008; Fig. 2).

To synthetize, the Campanian-Maastrichtian period was characterized by the deposition of white neritic carbonates along much on the Pontides. The Paleocene sequence is dominated by marls, sandstones and limestones in the Eastern Pontides as in the Central Pontide Arc. Even if volcanism is attested until the Late Campanian at Çalkoy (Fig. 8), and very locally, at Bayburt and Ordu (Fig. 2), during the Paleocene, it generally stopped along all the Pontides from the Middle Campanian to the Eocene (Fig. 3).

\section{Eocene}

The Eocene period is characterized by a general transgression over much of the Pontides (e.g. Yiğitbaş et al. 1999). Whereas mainly sedimentary rocks fill syncompressional basins in the Western and Central Pontides, both sedimentary and volcanic rocks with various formation names are present in the Eastern Pontides.

\section{Eocene in the Central Pontide Arc}

In the Central Pontide Arc, the Eocene is mainly represented by marls, sandstones turbiditic sandstones and conglomerates of the Kusuri and Cemalettin formations (Aydın et al. 1986; Tüysüz 1990; Görür \& Tüysüz 1997; Leren 2003; Janbu et al., 2007; Fig. 3a). Volcanic rocks are present locally, to the south of Kastamonu and within the Devrek basin, where they overlie Lutetian sedimentary rocks (nannoplankton zone NN14, sample 6-62, Hippolyte et al. 2010). The distribution of the Eocene sediments differs with those of older formations because they fill intra-mountain compressional basins: Karabük Basin, Eflani Basin, Kastamonu Basin, Devrekani Basin, and Boyabat Basin (e.g. Kaymakci et al. 2003a,b, 2009; Hippolyte et al. 2010; Fig. 1). The thickness of the Eocene sequence reaches $1200 \mathrm{~m}$ within the Boyabat basin (Şen 2013). The marine infill of these syn-thrusting basins started during the Early Eocene (nannoplankton zone NP12) and ended during the Middle Eocene (zone NP17; Fig. 3a) (Hippolyte et al. 2010). However, sedimentation was not uniform because it was controlled by flexural subsidence and local thrusting (Janbu et al., 2007). For example, during the Early Eocene the Sinop Range split the original Sinop-Boyabat Basin into two basins (Fig. 1; Janbu et al., 2007). In most of the syn-compressional basins, as in the Eocene Boyabat Basin, marine sedimentation only occurred during the EarlyMiddle Eocene (nannoplankton zones NP12-NP14; Fig. 3b; Hippolyte et al. 2010), whereas within the Sinop Basin, marine sedimentation also occurred during the Miocene (e.g. Y1lmaz et al. 1997). 


\section{Eocene in the Eastern Pontides}

In the Eastern Pontides, Eocene rocks are exposed in three main zones: within an inner volcanic arc along the Black Sea coast (Ordu, Trabzon, Rize); within an outer volcanic arc that roughly follows the southern slope of the mountain belt (Samsun, Erbaa, Gümüsshane, Bayburt, Olur); and within outer synclines on the external thrust sheets (Figs $2 \& 15$ ). These later are probably compressional thrusttop piggyback basins like those of the Central Pontide Arc (e.g. Kaymakci et al. 2003a, b, 2009; Hippolyte et al. 2010; Meijers et al. 2010; Robertson et al. 2014; Fig. 15). South of these piggyback basins, Oligocene-Miocene sediments, mainly deformed by salt tectonics (Callot et al., 2014), fill a large foreland basin extending from Sivas to Erzurum (Figs 2 \& 15).

A good section of the Eocene sequence, which unconformably overlies Santonian volcaniclastic sandstones to Maastrichtian rocks, can be studied near Olur (Dağdibi and Karataş Formation; Bozkuş 1992; Robertson et al. 2014; Fig. 5). It starts with transgressive oyster-bearing shallow marine clays, sands and sandstones of Early Eocene age (NP12 zone, samples E95, E96 and E97); an alternation of clays, sands, sandstones and conglomerates, with grey, yellow and pink coloration then forms a $>1500 \mathrm{~m}$ thick sedimentary sequence. An upper marly layer, locally with nummulites (sample E102) has nannoplankton assemblages from the NP12 zone (Early Eocene, sample E98) to the NP17 zone (Middle-Late Eocene, samples E102 and 105). It is overlain by a $>1200$ m thick volcanogenic sequence of Middle-Late Eocene age (zone NP17, samples E99, E100, E101, and E106).

In the Olur and the Kale areas (Fig. 2), the deposition of transgressive Eocene marine sediments started during the Ypresian (Early Eocene, nannoplankton zones NP12 and perhaps NP11; Figs. 5 and 6). At Kale a few intrusive bodies dated by $\mathrm{Ar}-\mathrm{Ar}$ ages to between 48 and $50 \mathrm{Ma}$ attest for subsequent (Ypresian-Lutetian) adakitic volcanic activity (e.g. Karsli et al. 2010; Eyuboglu et al 2013; Fig. 6). However, the thick non-adakitic volcanic and volcaniclastic accumulation of the Alibaba Formation post-dates the Ypresian (Eyuboglu et al. 2013; Fig. 6). Effectively, sample S90 of volcaniclastic sediments intercalated in the volcanic sequence shows Middle Eocene nannoplankton assemblages, probably of Late Lutetian age (zone NP16?; Fig. 6). We infer that, in the Kale area, the outer volcanic arc mainly formed during the Middle Eocene (Fig. 6). Similarly, in the Olur area the volcanic activity only started during the Latest Middle Eocene (zone NP17; Bartonian). In conclusion, with the exception of the adakitic intrusive bodies of Kale, the construction of the outer volcanic arc postdated the Ypresian. The Early Eocene was characterised by the deposition of nonvolcanogenic sediments (Fig. 3c). This period of very low volcanism in the outer Eastern Pontides globally corresponds to the deposition of non-volcanogenic sediments in the Western and Central Pontides (zones NP12 to NP17; Figs 3a and $3 b)$.

Along the Black Sea coast, in the Ünye-Ordu area (Fig. 2), the Eocene volcanic activity post-dates the Early Eocene zone NP13 (samples W113; Fig. 10). The Çalkoy section (Figs 2 and 8) indicates that the accumulation of thick Eocene volcanic rocks started during the Early Lutetian (zone NP14 of earliest Middle Eocene age). We conclude that the main construction of the inner volcanic-arc began before that of the outer volcanic-arc (Fig. 3c). In the Hopa-Borçka area (Fig. 2), volcanic rocks yielded ${ }^{40} \mathrm{Ar}-{ }^{39} \mathrm{Ar}$ ages from $46.9 \pm 0.1$ to $39.9 \pm 0.5 \mathrm{Ma}$ (Lutetian, equivalent to zones NP15-NP16; Aydınçakır \& Şen 2013). This also suggests that the thick accumulation of volcanic rocks along the Black Sea coast started slightly before those of the outer volcanic-arc (Kale and Olur areas; Fig. 2). These differences in the ages for the main effusive activity of the two volcanic arcs 
suggest that magmatism propagated southwards during the Middle Eocene (Fig. 15). This southwards propagation contrasts with the previous northwards younging of the adakitic volcanic activity, from $55.83 \pm 0.04$ Ma near Erzincan to $47.9 \pm 0.7$ to the south of Bayburt (Eyuboglu et al. 2011; Fig. 2).

We only have a few samples from the outer Eocene piggyback basins (in brown in figures 2 and 15). Within the Kelkit basin (samples S121, 123; Fig. 2) and within the Balkaya basin located to the south of Gümüshane (samples S133 to 137, Fig. 2), green volcanogenic sandstone yielded nannoplankton assemblages of Latest Middle Eocene age (NP17 nannoplankton zone of Bartonian age). This age is compatible with the age of the outer volcanic arcs. It suggests that compressional deformation and thrusting, related to these probable piggyback basins, were contemporaneous of the volcanic activity. This interpretation is also supported by our multiple observations of strike-slip and reverse faults cutting the volcanogenic sequence. Note that the NN17 nannoplankton zone (Bartonian, Fig.3c) is the age of the most recent marine sediments within piggyback basins as in the Central Pontide Arc (Fig. 3a). This suggests that compressional deformation occurred contemporaneously all along the Pontides.

\section{Geodynamic implications and conclusions:}

Along the southern margin of the Black Sea, the Central Pontide Arc is characterized by Early Cretaceous basins filled with clastic rocks. The infill of the Boyabat basin presents strong similarities in facies (turbidites with olistoliths), and in age with that of the Ulus flysch basin. These similarities include the occurrence of a Mid-Cretaceous sedimentary gap (Fig 3a, 3b). They suggest that, during the Early Cretaceous, these two basins were equivalent deep basins along the Eurasian active margin (Fig. 15). The fact that the Western and Central Pontides display similar Cretaceous sequence also suggests that the İstanbul and Sakarya zones were already welded during the Early Cretaceous. This contradicts previous models (e.g. Okay et al., 1994), but agrees with a recent interpretation (based on detrital zircon ages) that a large turbidite submarine fan covered much of the Central Pontides during the Early Cretaceous (Okay et al 2013). However, stratigraphic data support the idea that the deposition of the Lower Cretaceous sediments was controlled by tectonic deformation. The neritic sediments of the Çağlayan Group were deposited within rift basins along the present Black Sea margin (Fig. 15), whereas the flysch sediments were deposited within deep basins that fringed the active margin. Both basins resulted from the drowning of the Upper-Jurassic Lower Cretaceous İnalt1 carbonate platform controlled by normal faults (Espurt et al., 2014, Hippolyte et al., 2015). Therefore, the fact that the Early Cretaceous flysch basins of the Central Pontide Arc did not extend into the Eastern Pontides (Fig. 15) indicates that contrasting geodynamic conditions prevailed along the Pontides. It supports the interpretation that the opening of the western Black Sea Basin was triggered during the Early Cretaceous, before the opening of the eastern Black Sea Basin (e.g. Görür 1988).

Observation of angular unconformities (Hippolyte, et al., 2010; Fig. 4) indicates that much of the Central Pontides was emerged and undergoing erosion during the Middle Cretaceous. Emersion started during the earliest Late Albian and the resulting Mid-Cretaceous stratigraphic hiatus extends in places from the Upper Albian to the Coniacian (Fig. 3a and b). This emersion could be a consequence of the collision of the Karg1 continental block (Okay et al. 2006) or of the collision of oceanic volcanic arcs and plateaus with the Eurasian margin (Okay et al. 2013). During the Early Cretaceous the Eastern Pontides (Fig. 3c) and the Lesser Caucasus were also emerged. Sosson et al. (2010) attribute the Early Cretaceous uplift and 
erosion of the Lesser Caucasus to the subduction of the spreading ridge of the Sevan-Akera intra-oceanic back-arc basin. Taking into account the fact that the Sevan-Akera suture zone is the eastward prolongation of the Izmir-AnkaraErzincan suture zone in Turkey (e.g. Barrier and Vrielynck, 2008; Sosson et al., 2010; Hässig et al., 2014; Meijers et al., 2015), it is also possible that the subduction of the Sevan-Akera spreading ridge was the cause of the Middle Cretaceous uplift of the Pontides.

Our stratigraphic data in the Pontides and a synthetic stratigraphic study in Armenia and Georgia (Sosson et al., 2010) indicate that the Mid-Cretaceous emersion was followed during the Coniacian-Santonian by a marine transgression over a wide area extending from the Western Pontides to the Lesser Caucasus (Fig. 1 and 3). In the Pontides, the transgressive sequence includes typical red pelagic limestones (Kapanboğazı Formation; Görür et al. 1993), generally intercalated within a volcanogenic sequence. They have been interpreted as the syn-break-up succession of the western Black Sea Basin (Görür et al. 1993; Görür 1997; Tüysüz et al. 2012). Even if the deposition of these red beds was related to the subsidence of the Black Sea Basin, their geodynamic interpretation is questionable with respect to the global distribution of the CORBs (Hu et al. 2005). We pointed out that, in the Pontides, beds of red pelagic limestone were deposited both on the southern margin of the western and eastern Black Sea basins and along the active margin (Fig. 1). Stratigraphic ages based on nannoplankton assemblages indicate that their deposition occurred during at least three periods: the Santonian (all along the Pontide volcanic arc), the Early Campanian; and the Late Campanian (mainly in the Eastern Pontides). Thickness variations in the Upper Cretaceous series in the Central Pontides (Hippolyte et al. 2015), together with stratigraphic variations in the Eastern Pontides (Hopa-Borçka section compared with the Çalkoy and Of sections; Figs 12, 8 \& 11), and the occurrence of slumped beds of red pelagic limestone in the Central and Eastern Pontides (Fig. 9), suggest that their deposition occurred during extensional faulting related to the opening of the Black Sea basins. We infer that, after the Mid-Cretaceous uplift of the Central Pontide Arc, extensional deformation resumed along the western Black Sea Basin and propagated eastward to the eastern Black Sea Basin during the Santonian.

An eastward propagation of the opening of the Black Sea also seems to be indicated by the age of the Late Cretaceous volcanic arc. The volcanogenic sequence is apparently slightly younger in the Eastern Pontides (from the Santonian to the Late Campanian) than in the Western Pontides (from the Turonian (Tokay, 1952: Tüysüz, 1999) to the Santonian (Hippolyte et al. 2010)) (Fig. 3). The eastwards propagation of the Black sea opening could be related to an oblique subduction of the Sevan-Akera ridge.

We emphasize that, along the Pontides, the Campanian-Paleocene is an essentially non-volcanic period. We correlate the end of activity of the Pontide volcanic arc to a subduction jump from the north to the south of the AnatolideTauride-South Armenian microplate at c. $80 \mathrm{Ma}$ (Rolland et al. 2012; Fig. 15).

From the Early Campanian to the Late Paleocene, carbonate platforms and carbonate slope-apron systems were built along the Upper Cretaceous volcanic arc, as shown by the carbonaceous sequences of the Akveren Formation in the Central Pontide Arc, and Tonya Formation in the Eastern Pontides (Fig. 3). Contemporaneously, submarine fans of mainly siliciclastic turbidites were emplaced in the Central Pontides (Gürsökü Formation) and near Gümüşhane (Fig. 6). In the Eastern Pontides, the deposition of the post-volcanic sequence was mainly controlled by extensional faulting as attested by slumps, debris flow intercalations, olistoliths and normal faults. These elements support the interpretation, based on 
offshore seismic lines, that extensional block faulting of the eastern Black Sea Basin continued until the Palaeocene (Robinson et al. 1996).

Marine sedimentation within Eocene synclines along the Central Pontide Arc and within the Eastern Pontides dates from the Ypresian to the Bartonian (nannoplankton zones NP12-NP17; Fig. 3). This contemporaneous infill of the piggyback basins supports simultaneous compressional deformation related to the collision of the Tauride-Anatolide block all along the Pontides (Fig. 15).

In the Eastern Pontides, significant volcanism occurred after the Campanian-Paleocene extensional period and created two Eocene volcanic arcs. Stratigraphic ages indicate that the outer Eocene volcanic arc is about 7 myr younger than the inner volcanic-arc (Figs. 3c \& 15). The Eocene magmatism is usually attributed to the late evolution of the Tethyan oceanic slab (e.g. Şengör et al. (2003). We point out that it occurred during the infill of piggyback (compressional) basins (e.g. the Kelkit basin Fig. 2). Hence, this magmatism occurred after back-arc extension and during the Eocene collision of the AnatolideTauride Block. The southward propagation of this syn-collisional magmatism could reflect the rollback of the northward subducted slab, possibly accompanied by lithospheric delamination (e.g. Robertson et al. 2014; Fig. 15) and followed by its break-off during the Miocene (e.g. Şengör et al. 2003). Slab rollbacks are, however, usually associated with back-arc extension (e.g. Rolland et al., 2011). In the Eastern Pontides, the southwards propagation of the Eocene magmatism could reflect a syncollisional slab steepening under the Eastern Pontides, as proposed for the Miocene collision-related volcanism of eastern Anatolia (Keskin, 2003). Note that important magmatic activity also occurred along the Lesser Caucasus from the Late Eocene to the Miocene. It has been interpreted as the consequence of the asthenospheric upwelling that followed slab retreat and break-off (Sosson et al., 2010). In the Eastern Pontides, the southwards migration of the upwelling asthenosphere during the Eocene is supported by the stratigraphic ages (Fig. 3c).

Finally, a significant difference between the Eastern Pontides and the Central Pontide Arc is that the Eastern Pontides experienced relatively younger extensional deformation phases. Another difference is the formation of large Eocene volcanic arcs in the Eastern Pontides after the last extensional event of Campanian-Paleocene age. The boundary between the Central Pontide Arc and the Eastern Pontides (around Ünye; Fig. 15) corresponds offshore to the Mid Black Sea High. Therefore, stratigraphic comparison of the Eastern Pontides with the Central Pontide Arc supports the idea that the eastern Black Sea Basin is younger than the western Black Sea Basin (e.g. Robinson et al. 1996; Spadini et al. 1996; Cloetingh et al. 2003).

\section{ACKNOWLEDGMENTS}

This work was supported by Darius program sponsored by bhpbiliton, BP, CNRS-INSU, ENI, Maersk Oil, Petronas Garigali, Shell, Statoil, Total and the University Paris-6. We acknowledge the reviewers, Yann Rolland and Okan Tüysüz, for their useful comments. 


\section{Figure Captions}

Fig. 1: Geological map of the Jurassic to Eocene rocks of the Pontides (modified from Akdeniz 2002; Akdeniz \& Güven 2002; Aksay et al. 2002; Hakyemez \& Papak 2002; Ugüz et al. 2002). Inset figure: tectonic map of the Black Sea region. The mapping of the Dereköy Formation is from Tüysüz et al. (2012). Araç-Daday Shear Zone, West Crimea Fault and West Black Sea Fault, are from Y1lmaz et al. (1997), Okay et al. (1994) and Okay et al. (2013).

Fig. 2: Geological map of the Eastern Pontides with location of the sampled sections (names on yellow background), location of the samples of red pelagic limestone (text on pink background) and location of samples W59 and W63 from Jurassic-Lower Cretaceous limestone (text on gray background) (modified from Akdeniz 2002; Akdeniz \& Güven 2002; Hakyemez \& Papak 2002).

Fig. 3: Comparison of the age of the stratigraphic series of the (a) Western Pontides (164 samples; Hippolyte et al. 2010), (b) the Central Pontides (32 samples; Hippolyte et al. 2015) and (c) the Eastern Pontides (174 samples; this work) obtained by the determination of nannoplankton assemblages. For the Eastern Pontides, the absolute ages of volcanic rocks $(46.9 \pm 0.1$ to $39.9 \pm 0.5 \mathrm{Ma})$ are from Aydınçakır \& Şen (2013).

A-T: Akarsu-Trabzon section; CEM: Cemaller Formation; DER: Dereköy Formation of Middle Turonian-Early Santonian age, based on foraminiferal assemblages (Tüysüz et al. 2012); INP, İnpiri Formation; KAP: Kapanboğazı Formation; KIL: Kilimli Formation; SAP: Sapça Formation; TAS: Tasmaca Formation; VEL: Velibey Formation; YEM: Yemişliçay Formation;

Fig. 4: Red limestone of the Kapanboğazı Formation, unconformably overlying siliciclastic sediments of the Çağlayan Group. (a) In the south of the Boyabat Basin (Fig. 1; coordinates UTM36: 619711E; 4614622N); (b) In the north of the Boyabat Basin (coordinates UTM36: 658221E; 4611209N) where the Kapanboğazı Formation yield nannoplankton assemblages of Santonian-Early Campanian age (Hippolyte et al., 2015).

These unconformities, similar to those observed in the Western Pontides (Hippolyte et al., 2010) demonstrate that there was emersion and erosion during the MiddleCretaceous in the Central Pontide Arc. This erosional event explains the MidCretaceous stratigraphic hiatus locally indicated by nannoplankton age data (Fig. $3)$.

Fig. 5: Schematic stratigraphic section (not to scale) and nannoplankton ages of the Olur area (Fig. 2). The rock formations and ages according to Bozkuş (1992) are given in blue lettering. A thick Eocene sequence overlies Cretaceous volcanic rocks and volcaniclastic sandstones of Santonian age. Eocene volcanic rocks are not older than Bartonian (NP17 zone). The Maastrichtian carbonates of the Akbayir Formation (Bozkus 1992) are missing on the studied section. The sequence ends with non-dated terrestrial clastic rocks of probable Oligocene age and PlioceneQuaternary volcanic rocks.

Fig. 6: Schematic stratigraphic section (not to scale) and nannoplanktons ages at Kale (20 km east of Gümüşhane) on the southern slope of the Eastern Pontides (Fig. 2). Ages and data from previous authors are given in blue lettering. The Campanian 
age of red pelagic limestone and marl (Eren \& Tasli 2002) is confirmed by samples (S93).

Fig. 7: Schematic stratigraphic section (not to scale) and nannoplanktons ages on the northern slope of the Eastern Pontides, between Akarsu and Trabzon (Fig. 2). The red pelagic limestone intercalated within the thick Santonian-Lower Campanian volcanic and volcaniclastic sequence is of Santonian age as in the Central Pontide Arc (Fig. 3).

Fig. 8: Schematic stratigraphic section (not scaled) and nannoplanktons ages on the northern slope of the Eastern Pontides, Çalkoy village area (Trabzon) (Fig. 2). The Tonya Formation was studied on this section by İnan et al. (1999). Two members of red pelagic limestone are present. Volcanic activity stopped during the Late Campanian, and restarted during the Early-Middle Eocene.

Fig. 9: Examples of relationship between the red pelagic limestone and the volcaniclastic sandstones at sites W33 and W67 (Fig. 2). (a) vertical beds of red limestone without intercalations of volcaniclastic sediments; (b) and (d) intercalations of volcaniclastic sandstones (v.s.) and red limestone; (c) and (e) slumped layers of red limestone; (f) typical beds of red limestone with thin clay interbeds; (g) probable radiolarian chert layer; (h) mud balls of red limestone within a sandy matrix including volcanic clasts (hammer for scale).

Fig. 10: Synthetic stratigraphic section of graben infill in the Ünye-Ordu area, based on the age determination of 36 samples (Fig. 2). Rock formations and ages according to Terlemez \& Yilmaz (1980) are given in blue lettering. The Campanian-Palaeocene series of limestones and marls (Fig. c, b, i) are often cut by normal faults (Fig. j). Debris-flow deposits and olistoliths of volcanic rocks intercalated within the stratigraphic sequence (Fig. d, e, f, g, h) probably result from the erosion of the pre-Campanian rocks along bounding fault scarps and horsts. Volcanic activity is attested during the Early Palaeocene (sample W78), but mainly occurred after the Ypresian (sample W113) from the Eocene to the Pliocene (Fig. a; Terlemez \& Y1lmaz 1980).

Fig. 11: Schematic stratigraphic section (not to scale) and nannoplankton ages along the Black Sea at Arakli and Of (Fig. 2). The Tonya carbonate sequence was deposited above the Kermutdere volcanogenenic sequence from the Early Campanian to the Late Maastrichtian.

Fig. 12: Schematic stratigraphic section (not to scale) and nannoplankton ages along the Black Sea between Hopa and Borçka (Fig. 2). Ages and data from previous authors are given in blue lettering. ${ }^{40} \mathrm{Ar}-{ }^{39} \mathrm{Ar}$ ages of volcanic rocks near Borçka indicate Middle Eocene (from $46.9 \pm 0.1$ to $39.9 \pm 0.5 \mathrm{Ma}$ ) volcanic activity (Aydınçakır \& Şen 2013) in agreement with stratigraphic ages along the Black Sea coast (NP14 at Çalkoy, Fig. 8, and NP17 north of Hopa, this figure).

Fig. 13: Geological map of the Ünye-Ordu area (Fig. 2) with location of the dated samples (modified from Hakyemez \& Papak 2002). The Campanian-Palaeocene series of limestone and marl (Fig. 10) were deposited within graben structures. Eocene rocks overlie these extensional structures. 
Fig. 14: Middle Palaeocene-Lowest Eocene stratigraphic sequence of the Ardanuç Basin on the southern slope of the Eastern Pontides (nannoplankton zones NP6NP9; Figs. 2 and 3c).

Fig. 15: Geological map of the Pontides with the main structural domains interpreted according to their stratigraphic evolution. Same legend as in figures 1 and 2.

Note the spatial distribution of the red pelagic limestone (in pink) along the whole Pontide belt. The facts that the Boyabat flysch basin and the Ulus flysch basin (Fig. 1) had the same stratigraphic evolution (Fig. 3), and that they were located along the active margin, suggest that they formed a single deep fore-arc basin during the Early Cretaceous. The main extensional subsidence migrated along the Pontides from the Lower Cretaceous basins of the Central Pontide Arc, to the Upper Cretaceous Sinop-Boyabat Basin, and to the Campanian-Paleocene basins of the Eastern Pontides. During the Eocene, magmatism propagated from the inner volcanic arc to the outer volcanic arc. The outer Eocene basins of the Eastern Pontides are interpreted as piggyback basins. The Oligocene-Miocene deposits located at the south of the Eastern Pontides (in yellow; e.g. Callot et al., 2014) constituted the foredeep basin of the Eastern Pontides.

Table 1: Coordinates (UTM, WGS84), age, and nannofossils of the 174 dated samples (109 sites).

\section{References}

Akat, U., Akçören, F., E.Altun, İ., Devciler E., Göktunalı, K., Keskin, H., Sevin, M., \& Y1ldırım, M. 1990. Geologic Map of the Kastamonu B-17 Quadrangle, 1:100 000. Maden Tetkik ve Arama Genel Müdürlüğü, Ankara.

Akbayram, K, Okay, A. I. \& Satır, M. 2013. Early Cretaceous closure of the IntraPontide Ocean in western Pontides (northwestern Turkey). Journal of Geodynamics, 65, 38-55

Akdeniz, N. 2002. Geological map of Turkey, 1:500 000, Kars. General Directorate of mineral research and exploration, Ankara.

Akdeniz, N. \& Güven, I., H. 2002. Geological map of Turkey, 1:500 000, Trabzon. General Directorate of mineral research and exploration (MTA), Ankara.

Aksay, A., Pehlivan, S., Gedik, I., Bilginer, E., Duru, M., Akbas, B. \& Altun I. 2002. Geological map of Turkey, 1:500 000, Zonguldak. General Directorate of mineral research and exploration (MTA), Ankara.

Akyol, Z., Arpat, E., Erdoğan, B., Göğer, E., Güner, Y., Şaroğlu, F., Şentürk, İ., Tütüncü, K. \& Uysal, Ş. 1974. Geologic Map of the Cide-Kurucaşile region. Quadrangle Series. E29a, E29b, E29c, E29d, E30a, E30b. Mineral Research and Exploration Institute of Turkey (MTA), Ankara,Turkey.

Alan, I., Aksay, A. 2002. Geological map of the Zonguldak E27-F27 quadrangles, 1:100 000. General Directorate of Mineral research and exploration (MTA), Ankara, Turkey.

Altherr, R., Topuz, G., Siebel, W., Şen, C., Meyer, H.-P., Satır, M. \& Lahaye, Y. 2008. Geochemical and $\mathrm{Sr}-\mathrm{Nd}-\mathrm{Pb}$ isotopic characteristics of Paleocene plagioleucitites from the Eastern Pontides (NE Turkey). Lithos 105, 149-161. http://dx.doi.org/10.1016/j.lithos.2008.03.001. 
Aydın, M, Şahintürk, Ö, Serdar, H.S., Özçelik, Y., Arkasu, I, Üngör, A., Cokugras, R. \& Kasar, S. 1986., The geology of the area between Ballıdağ and Çangaldağ (Kastamonu). Geological Society of Turkey Bulletin, 29, 1-16 (in Turkish with English abstract).

Aydınçakır, E. \& Şen, C. 2013. Petrogenesis of the post-collisional volcanic rocks from the Borçka (Artvin) area: Implications for the evolution of the Eocne magmatism in the Eastern Pontides (NE Turkey). Lithos, 172-173, 98-117.

Barrier, E. \& Vrielynck, B. 2008. Palaeotectonic map of the Middle East, Atlas of 14 maps, Tectonosedimentary-Palinspastic maps from Late Norian to Pliocene. Commission for the Geologic Map of the World (CCMW, CCGM), Paris, France.

Bektaş, O., Yılmaz, C., Taslı, K., Akdağ, K. \& Özgür, S. 1995. Cretaceous rifting of the eastern Pontide carbonate platform (NE Turkey): the formation of carbonates breccias and turbidites as evidences of a drowned platform. Geologia, 57, 1-2, 233-244.

Bozkurt, E., Winchester, J. A. \& Satır, M. 2012. The Çele mafic complex: Evidence for Triassic collision between the Sakarya and Istanbul Zones, NW Turkey, Tectonophysics, 595-596, 198-214.

Bozkuş, C. 1992. Olur (Erzurum) Yöresinin stratigrafisi. Geological Bulletin of Turkey, 35, 103-119.

Callot, J. P., Ribes, C., Kergaravat, C., Bonnel, C., Temiz, H., Poisson, A., Vrielynck, B., Salel, J. F. \& Ringenbach, J. C. 2014. Salt tectonics in the Sivas basin (Turkey): crossing salt walls and minibasins. Bulletin de la Societe Geologique de France, 185, 33-42.

Cloetingh, S., Spadini, G., Van Wees, J.D. \& Beekman, F. 2003. Thermo-mechanical modelling of the Black Sea Basin (de)formation. Sedimentary Geology, 156, 169-184.

Derman, S., \& Say1l, A. 1995. İnaltı Formation: a key unit for regional geology. In: ERLER, A., ERCAN, T., BINGÖL, E. \& ÖRÇEN, S. (eds) Geology of the Black Sea Region, Proceedings of the International Symposium on the Geology of the Black Sea Region. Mineral Research and Exploration Institute of Turkey (MTA), 104-108.

Elmas, A. \& Yiğitbaş, E. 2001. Ophiolite emplacement by strike-slip tectonics between the Pontide Zone and the Sakarya Zone in Northwestern Anatolia, Turkey, International Journal of Earth Sciences, 90, 2, 257-269.

Eren, M. \& Tasl1, K. 2002. Kilop Cretaceous hardground (Kale, Gümüşhane, NE Turkey): description and origin. Journal of Asian Earth Sciences, 20, 433-448.

Espurt, N., Hippolyte, J. C., Kaymakci, N. \& Sangu E. 2014. Lithospheric structural control on inversion of the southern margin of the Black Sea Basin, Central Pontides, Turkey. Lithosphere, 6, 1, 26-34, http://doi.org/10.1130/L316.1

Eyuboglu Y., Santosh, M., Dudas, F. O., Chung S. L. \& Akaryal1, E. 2011. Migrating magmatism in a continental arc: Geodynamics of the Eastern Mediterranean revised. Journal of Geodynamics, 52, 2-15.

Eyuboglu, Y., Santosh, M., Dudas, F. O., Akaryal1, E., Chung S. L., Akdag, K. \& Bektaş O. 2013. The nature of transition from adakitic to non-adakitic magmatism in a slab window setting: A synthesis from the eastern Pontides, NE Turkey. Geoscience Frontiers, 4, 353-375

Finetti, I., Bricchi, G., Del Ben, A., Pipan, M. \& Xuan, Z. 1988. Geophysical study of the Black Sea. Bolletino di Geofisica ed Applicata, 30, 197-324. 
Gedik, I., Aksay, A. 2002. Geological map of the Zonguldak E29 quadrangle, 1:100 000. General Directorate of Mineral research and exploration (MTA), Ankara, Turkey.

Görür, N. 1988. Timing of opening of the Black Sea Basin. Tectonophysics, 147, 247262.

Görür, N. 1997. Cretaceous syn- to post-rift sedimentation on the southern continental margin of the western Black Sea Basin. In: Robinson A.G. (Editor), Regional and petroleum geology of the Black Sea and surrounding region. AAPG Memoir, 68, 227-240.

Görür, N., Oktay, F. Y., Seymen, I. \& Şengör, A. M. C. 1984. Paleotectonic evolution of the Tuzgölï basin complex, Central Anatolia: Sedimentary record of a NeoTethyan closure. In: DIXON, J.E. \& ROBERTSON, A. H. F. (eds.) The geological evolution of the Eastern Mediterranean. Geological Society of London, Special Publication, 17, 455-466.

Görür, N., Tüysüz, O., Aykol, A., Sakinc, M. Yigitbas, E. \& Akkök R. 1993. Cretaceous red pelagic carbonates of northern Turkey: Their place in the opening history of the Black Sea. Eclogae Geology Helvetica, 86, 3, 819-838.

Görür, N, \& Tüysüz O. 1997. Petroleum Geology of the Southern Continental Margin of the Black. In: ROBINSON, A.G. (ed) Regional and Petroleum Geology of the Black Sea and Surrounding Region, AAPG Memoir, 68, 241-254

Graham, R., Kaymakci, N. \& Horn, B. 2013. Revealing the Mysteries of the Black Sea. GeoExpro,10/5, 58-63.

Hakyemez, H. Y \& Papak, I. 2002. Geological map of Turkey, 1:500 000, Samsun. General Directorate of mineral research and exploration, Ankara.

Hässig, M., Rolland, Y., Sosson, M., Galoyan, G., Sahakyan, L., Topüz, G., Celik, O.F., Avagyan, A. \& Müller C. 2014. Linking the NE Anatolian and Lesser Caucasus ophiolites: evidence for large scale obduction of oceanic crust and implications for the formation of the Lesser Caucasus-Pontides Arc. Geodinamica Acta, 26, 1-20

Hippolyte, J. C., Müller, C., Kaymakci, N. \& Sangu E. 2010. Dating of the Black Sea Basin: new nannoplankton ages from its inverted margin in the Central Pontides (Turkey). In: SOSSON, M., KAYMAKCI, N., STEPHENSON, R. A., BERGERAT F., \& STAROSTENKO, V. (eds). Sedimentary Basin Tectonics from the Black Sea and Caucasus to the Arabian Platform. Geological Society, London, Special Publication, 340, 113-136. http://doi.org/10.1144/SP340.7

Hippolyte, J-C,, Espurt, N., Kaymakci, N. , Sangu, E., Müller, C. 2015. Crosssectional anatomy and geodynamic evolution of the Central Pontide orogenic belt (northern Turkey) Int. J. Earth Sci, DOI 10.1007/s00531-015-1170-6

Hippolyte, J. C., Nury, D., Angelier, J. \& Bergerat, F. 1991. Relations tectonique extensive et sédimentation continentale: exemple des bassins oligocènes de Basse-Provence. Bulletin de la Société Géologique de France, 162, 6, 10831094.

Hsü, K.J., Nacev, I.K. \& Vuchev, V.T., 1977. Geologic evolution of Bulgaria in the light of plate tectonics. Tectonophysics, 40, 245-256.

Hu, X., Jansa, L., Wang, C., Sarti, M., Bak, K., Michael Wagreich, M., Michalik, J. \& Sotak, J. 2005. Upper Cretaceous oceanic red beds (CORBs) in the Tethys: occurrences, lithofacies, age, and environments. Cretaceous Research, 26, 320 . 
İnan, N., İnan, S. \& Kurt, İ. 1999. Conformable benthic K/T transition in the Eastern Pontides: Şahinkaya member of the Tonya Formation (SW Trabzon). Geological Bulletin of Turkey, 42, 2, 63-67.

Janbu, N.E., Nemec, W., Kırman, E. \& Özaksoy, V. 2007. Facies anatomy of a channelized sand-rich turbiditic system: the Eocene Kusuri Formation in the Sinop Basin, north-central Turkey. In: NICHOLS, G., PAOLA, C., \& WILLIAMS, E.A. (eds) Sedimentary Environments, Processes and Basins - A Tribute to Peter Friend. Int. Assoc. Sedimentol. Spec. Publ., 38, 457-517.

Karsli O., Dokuz A., Uysal İ., Aydin F., Kandemir R. \& Wijbrans, J. 2010. Generation of the Early Cenozoic adakitic volcanism by partial melting of mafic lower crust, Eastern Turkey: Implications for crustal thickening to delamination", LITHOS, 114, 109-120

Kaymakci, N., Duermeijer, C. E., Langereis, C., White, S.H., \& van Dijk, P. M. 2003b. Oroclinal bending due to indentation: a paleomagnetic study for the early Tertiary evolution of the Çankiri Basin (central Anatolia, Turkey) . Geological Magazine. 140/3, 343-355.

Kaymakci, N., Inceöz, M., Ertepinar, P. and Koç, A. 2010. Late Cretaceous to recent kinematics of SE Anatolia (Turkey) In Sosson, M. Kaymakci, N., Stephenson, R., Starostenko, V. and Bergerat, F. (Eds.) Sedimentary basin tectonics from the Black Sea and Caucasus to the Arabian Platform. Geological Society London Special Issue No. 340, 409-435.

Kaymakci, N., Özcelik, Y., White, S. H. \& Van Dijk, P.M. 2009. Tectonostratigraphy of the Çankiri Basin: Late Cretaceous to Early Miocene evolution of the Neotethyan Suture Zone in Turkey. In: VAN HINSBERGEN, D.J.J., EDWARDS, M.A. \& GOVERS, R. (eds), Geodynamics of Collision and Collapse at the Africa-Arabia-Eurasia subduction zone, Geological Society of London London Special Issue, 311, 67-106.

Kaymakci, N., White, S.H. \& van Dijk P.M. 2003a. Kinematic and structural development of the Çankiri Basin (Central Anatolia, Turkey). a paleostress inversion study. Tectonophysics, 364, 85-113.

Keskin, M., 2003. Magma generation by slab steepening and breakoff beneath a subduction-accretion complex: An alternative model for collision-related volcanism in Eastern Anatolia, Turkey. Geophysical Research Lettres, 30 (24), 8046, doi:10.1029/2003GL018019

Ketin, I. \& Gümüş, Ö. 1963. Sinop-Ayancik arasindaki III. bölgeye dahil sahalarin jeolojisi hakkinda rapor, 2. Kisim, Jura ve Kretase Formasyonlarinin etüdü. Türkiye Petrolleri Arama Grubu Arsivi (unpublished report) No. 213-288, 118p.

Koçyiğit A., \& Altıner, D. 2002. Tectonostratigraphic Evolution of the North Anatolian Palaeorift (NAPR): Hettangian-Aptian Passive Continental Margin of the Northern Neo-Tethys, Turkey. Turkish Journal of Earth Sciences, 11, 169191.

Konak, N., Okay, A. I. \& Hakyemez, H. Y. 2009. Tectonic and stratigraphy of the Eastern Pontides. $2^{\text {nd }}$ International symposium on the geology of the Black Sea region. Field trip guide book. $120 \mathrm{p}$.

Korkmaz, S. 1993. Stratigraphy of the Tonya-Düzköy (SW Trabzon) area, NE Turkey. Geological Bulletin of Turkey, 36, 151-158.

Leren, B. L. S. 2003. Late Cretaceous to Early Eocene sedimentation in the SinopBoyabat Basin, north-central Turkey: facies analysis of turbiditic to shallowmarine deposits. PhD thesis. Bergen University, Norway. 140 p.

Letouzey, J., Biju-Duval, B., Dorkel, A., Gonnard, R., Kritchev, K., Montadert, L. \& Sungurlu, O. 1977. The Black Sea: a marginal basin; geophysical and geological 
data. In : BIJU-DUVAL, B. \& MONTADERT, L. (eds), International Symposium on the Structural History of the Mediterranean Basins, Technip, Paris, 363-376.

Manetti, P., Boccaletti, M. \& Peccerillo, A. 1988. The Black Sea : remnant of a marginal basin behind the Srednegorie-Pontides island arc system during the Upper Cretaceous-Eocene times. Bolletino di Geofisica Teorica ed Applicata, 30, 39-51.

Masse, JP., Tüysüz, O., Fenerci-Masse M., Özer, S., \& Sari, B. 2009. Stratigraphic organisation, spatial distribution, palaeoenvironmental reconstruction, and demise of Lower Cretaceous (Barremian-lower Aptian) carbonate platforms of the Western Pontides (Black Sea region, Turkey). Cretaceous Research, 30, 1170-1180.

Meijers, M.J.M., Kaymakci, N., Van Hinsbergen, D.J.J., Langereis, C.G., Stephenson, R.A. \& Hippolyte, J-C. 2010. Late Cretaceous to Paleocene oroclinal bending in the central Pontides (Turkey). Tectonics, 29, TC4016, http://doi.org/:10.1029/2009TC002620.

Meijers, M.J.M., Smith, B., Kircher, U., Mensink, M., Sosson, M., Rolland, Y., Grigoryan, A., Sahakyan, L., Avagyan, A., Langereis, C. \& Müller, C. 2015. A paleolatitude reconstruction of the South Armenian Block (Lesser Caucasus) for the late Cretaceous: Constraints on the Tethyan realm. Tectonophysics, 644-645, 197-219. 10.1016/j.tecto.2015.01.012

Nikishin, A.M., Okay, A., Tüysüz, O., Demirer, A., Wannier, M., Amelin, N. \& Petrov, E. 2015a. The Black Sea basins structure and history: New model based on new deep penetration regional seismic data. Part 2: Tectonic history and paleogeography. Marine and petroleum Geology, 59, 656-670.

Nikishin, A.M., Okay, A., Tüysüz, O., Demirer, A., Amelin, N. \& Petrov, E. 2015b. The Black Sea basins structure and history: New model based on new deep penetration regional seismic data. Part 1: Basin structure and fill. Marine and petroleum Geology, 59, 638-655.

Okay, A. I., \& Şahintürk, Ö. 1997. Geology of the Eastern Pontides. In: ROBINSON, A. G. (ed) Regional and Petroleum Geology of the Black Sea and Surrounding Region. American Association of Petroleum Geologists Memoir, Tulsa, Oklahoma, 68, 91-311,

Okay, A. I., Şengör, A.M.C. \& Görür, N. 1994. Kinematic history of the opening of the Black Sea and its effect on the surrounding regions, Geology, 22, 267-270.

Okay, A. I., Sunal, G., Sherlock, S., Altiner, D., Tüysüz, O., Kylander-Clark, A.R.C \& Ayguil, M. 2013. Early Cretaceous sedimentation and orogeny on the active margin of Eurasia: Southern Central Pontides, Turkey. Tectonics, 32, 1-25, http://doi.org/:10.1002/tect.20077

Okay, A.I. \& Tüysüz, O. 1999. Tethyan Sutures of northern Turkey. In: DURAND, B., JOLIVET, L, HORVATH, F. \& SÉRANNE, M. (eds) The Mediterranean Basins: Tertiary Extension within the Alpine Orogen. Geological Society London, Special Publication, 156, 475-515.

Okay, A.I., Tüysüz, O., Satır, M., Özkan-Altıner, S., Altıner, D., Sherlock, S., \& Eren, R.H. 2006. Cretaceous and Triassic subduction-accretion, high-pressure-lowtemperature metamorphism, and continental growth in the Central Pontides, Turkey. Geological Society of America Bulletin, 118, 1247-1269.

Özer, S., Sarı, B., Yılmaz, C., Görmüş, M., Kandemir, R. \& Akdeniz, N. 2008. Kampaniyen-Mastrihtiyen İstiflerinin Rudist-Foraminifer Biyostratigrafisi, Fasiyes Analizi ve Paleobiyocoğrafik Özellikleri, Pontidler-Kuzey Türkiye. TÜBİTAK Project No: 106Y144 [unpublished]. 
Pelin, S. 1977. Alucra (Giresun) Guneydoðu Yöresinin Petrol Olanaklarý Bakýmýndan Jeolojik Ýncelemesi. Karadeniz Technical University Publication, 87, Trabzon, Turkey.

Rice, S. P., Robertson, A. H. F., Ustaömer, T., İnan, N. \& Tasli, K. 2009. Late Cretaceous-Early Eocene tectonic development of the Tethyan suture zone in the Erzincan area, Eastern Pontides, Turkey. Geological Magazine, 146, 567590.

Robertson, A. H. F. \& Dixon, J. E. 1984. Introduction: aspects of the geological evolution of the Eastern Mediterranean, In: DIXON, J.E. \& ROBERTSON, A. H. F., (eds), The Geological Evolution of the Eastern Mediterranean: Geological Society London Special Publication, 17, 1-74.

Robertson, A., Parlak, O., Ustaömer, T., Taslı, İnan, N., Dumitrica, P. \& Karaoğlan, F. 2014. Subduction, ophiolite genesis and collision history of Tethys adjacent to the Eurasian continental margin: new evidence from the Eastern Pontides, Turkey. Geodinamica Acta, http://doi.org/10.1080/09853111.2013.877240

Robinson, A., Rudat, J. H., Banks, C. J. \& Wiles, R. L. F. 1996. Petroleum geology of the Black Sea. Marine and Petroleum Geology, 13, 195-223.

Robinson, A. 1997. Introduction: Tectonic elements of the Black Sea region. In: ROBINSON, A. (ed) Regional and petroleum geology of the Black Sea and surrounding region, American Association of Petroleum Geologists Memoir, 68, 1-6.

Robinson, A. G., C. J. Banks, M. M. Rutherford \& Hirst J. P. P. 1995. Stratigraphic and structural development of the Eastern Pontides, Turkey. Journal of the Geological Society of London, 152, 861-872.

Rolland, Y., Perincekb, D., Kaymakcic, N., Sosson, M., Barrier, E. \& Avagyane, A. 2012. Evidence for $\sim 80-75$ Ma subduction jump during Anatolide-TaurideArmenian block accretion and $\sim 48 \mathrm{Ma}$ Arabia-Eurasia collision in Lesser Caucasus-East Anatolia. Journal of Geodynamics, 56-57, 76-85, http://doi.org/:10.1016/j.jog.2011.08.006

Rolland, Y., Sosson, M., Adamia, Sh. \& Sadradze, N. 2011. Prolonged 'Variscan to Alpine' history of Active Eurasian margin (Georgia, Armenia) revealed by 40Ar/39Ar dating. Gondwana Research, 20, 798-815.

Şen, Ş. 2013. New evidences for the formation of and for petroleum exploration in the fold-thrust zones of the central Black Sea Basin of Turkey. AAPG Bulletin, 97, 3, 465-485. http://doi.org/10.1306/09041212005

Şengör, A. M. C., Özeren, S., Genç, T., Zor, E. 2003. East Anatolian high plateau as a mantle-supported, North-south shortened domal structure. Geophysical Research Letters, 30 (24). http://doi.org/.org/10.1029/2003GL017858.

Şengör, A. M. C. \& Y1lmaz, Y. 1981. Tethyan evolution of Turkey: a plate tectonic approach. Tectonophysics, 75, 181-241.

Sofracioğlu, D., Kandemir, R. 2013. The Upper Cretaceous calciclastic submarine fan deposits in the Eastern Pontides, NE Turkey: facies architecture and controlling factors. Turkish Journal of Earth Sciences, 22: 588-610, http://doi.org/:10.3906/yer-1207-3

Sosson, M., Rolland, Y., Muller, C., Danelian, T., Melkonyan, R., Kekelia, M., Adamia, S.A., Babazadeh, V., Kangarli, T., Avagyan, A., Galoyan, G. \& Mosar, J. 2010. Subduction, obduction and collision in the Lesser Caucasus (Armenia, Azerbaijan, Georgia), new insights. In: SOSSON, M., KAYMAKCI, N., STEPHENSON, R. A., BERGERAT F., \& STAROSTENKO, V. (eds). Sedimentary Basin Tectonics from the Black Sea 
and Caucasus to the Arabian Platform. Geological Society, London, Special Publication, 340, 329-352. http://dx.doi.org/10.1144/SP340.14 0305-8719/10.

Spadini, G., Robinson, A. \& Cloeting, S. 1996. Western versus Eastern Black Sea tectonic evolution: pre-rift lithosphere controls on basin formation. Tectonophysics, 266, 139-154.

Terlemez, I. \& Y1lmaz, A. 1980. Stratigraphy of the area between Ünye-OrduKoyulhisar-Reşadiye. Bulletin of the Geological Society of Turley, 23, 179191.

Tokay, M. 1952. Contribution à l'étude géologique de la region comprise entre Eregli Alapli Kiziltepe et Alacaağzı. Maden Tetkik ve Arama Enstitüsü Mecmuasi (Mineral Res. and Explor. Inst. Bull.), 42-43, 37-78.

Tokel, S. 1972. Stratigraphical and volcanic history of the Gümüşhane region (Turkey), PhD Thesis, University College, London, 189 p.

Tüysüz, O., 1990. Tectonic evolution of a part of the Tethyside orogenic collage: the Karg1 Massif, northern Turkey, Tectonics, 9, 141-160.

Tüysüz, O., 1999. Geology of the Cretaceous sedimentary basins of the Western Pontides, Geological Journal, 34, 75-93.

Tüysüz, O., Y1lmaz, I. O., Svábenická, L. \& Kirici, S. 2012. The Unaz Formation: a key unit in the Western Black Sea region, N Turkey. Turkish Journal Earth Sciences, 21, 2012-1028.

Ugüz, M.F., Sevin, M. \& Duru, M. 2002. Geological map of Turkey, 1:500 000, Sinop. General Directorate of mineral research and exploration, Ankara.

Ustaömer, T. \& Robertson, A. H. F. 2010. Late Palaeozoic-Early Cenozoic tectonic development of the Eastern Pontides (Artvin area), Turkey: stages of closure of Tethys along the southern margin of Eurasia. In: STEPHENSON R. A. et al., (eds) Sedimentary Basin Tectonics from the Black Sea and Caucasus to the Arabian Platform. Journal of the Geological Society, Special Publications, 340, 281-327, http://doi.org/:10.1144/SP340.13.

Yegorova, T., Gobarenko, V. \& Yanovskaya, T. 2013. Lithosphere structure of the Black Sea from 3-D gravity analysis and seismic tomography. Geophysical Journal International, 193, 287-303, http://doi.org/: 10.1093/gji/ggs098

Yergök, A.F., Akman, Ü., Keskin, İ., İplikçi, E., Mengi, H., Karabalık, N.N., Umut, M., Armağan, F., Erdoğan, K., Kaymakçı, H. \& Çetinkaya, A. 1987. Batı Karadeniz Bölgesinin Jeolojisi (I), 1:100 000. Maden Tetkik ve Arama Genel Müdürlüğü, Ankara.

Yergök, A.F., Akman, Ü., Tekin, F., Karabalık, N.N., Arbaş, A., Umut, M., Armağan, F., Erdoğan, K. \& Kaymakçı, H. 1989. Batı Karadeniz Bölgesinin Jeolojisi (II), 1:100 000. Maden Tetkik ve Arama Genel Müdürlüğü, Ankara.

Yiğitbaş, E., Elmas, A. \& Yılmaz, Y. 1999. Pre-Cenozoic tectono-stratigraphic components of the Western Pontides and their geological evolution. Geological Journal, 34, 55-74.

Yilmaz, C. 2002. Tectono-sedimentary records and controlling factors of the Mesozoic sedimentary basins in the Gümüsshane-Bayburt region (in Turkish). Geological Bulletin of Turkey, 45, 1, 141-164

Yılmaz, Y., Tüysüz, O., Yiğitbaş, E., Genç, Ş.C. \& Şengör, A.M.C. 1997. Geology and tectonic evolution of the Pontides, In: ROBINSON, A. G. (ed) Regional and Petroleum Geology of the Black Sea and Surrounding Regions. The American Association of Petroleum Geologists Memoir, 68, 183-226.

Zonenshain, L.P. \& Le Pichon, X. 1986. Deep basins of the Black Sea and Caspian Sea as remnants of Mesozoic back-arc basins, Tectonophysics, 123, 181-211. 







\section{CENTRAL PONTIDE ARC}

(a) WESTERN PONTIDES

164 samples (Hippolyte et al., 2010)

(b) CENTRAL PONTIDES

32 samples (Hippolyte et al., 2015)

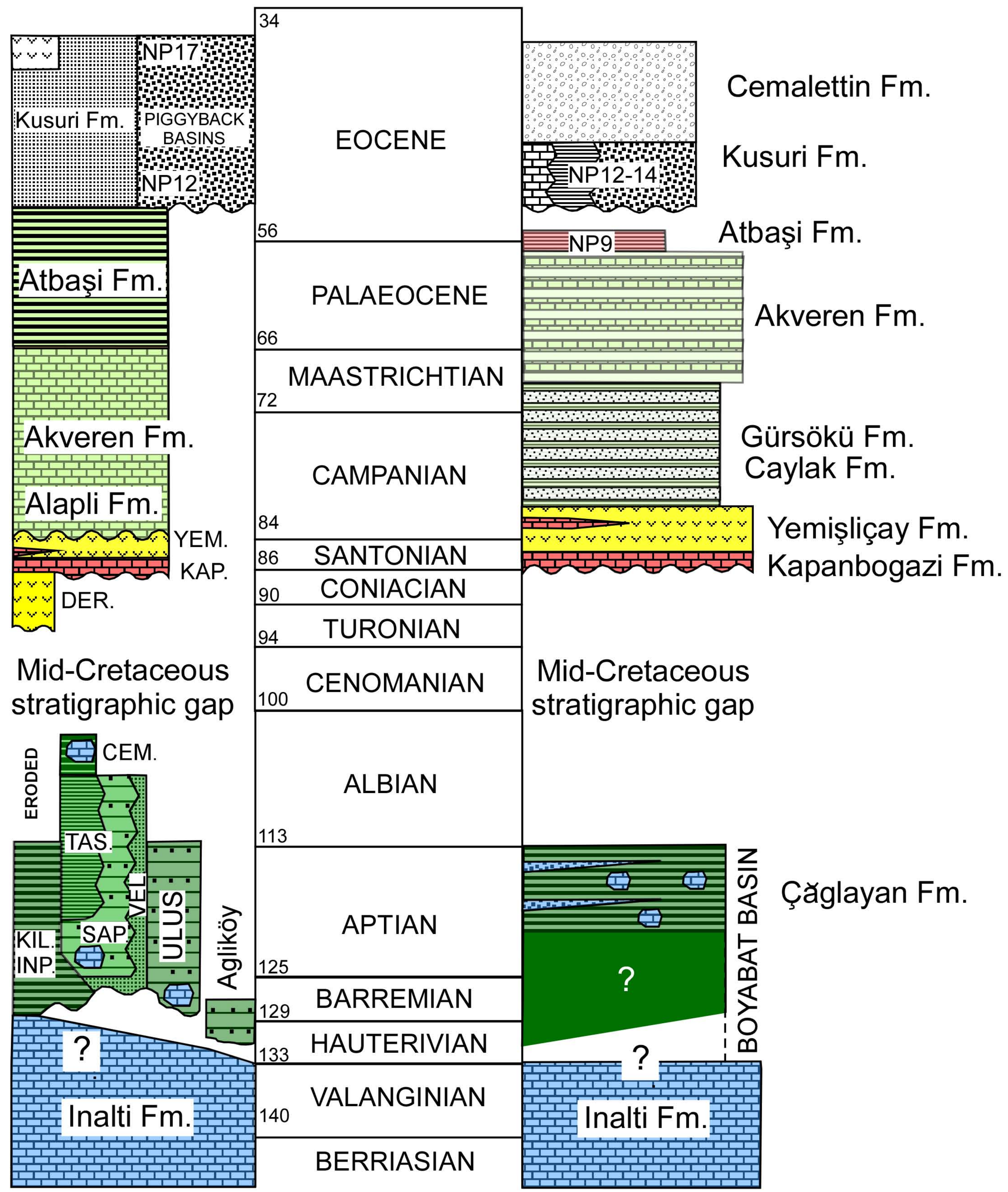

(c) EASTERN PONTIDES

174 samples (this work) outer arc

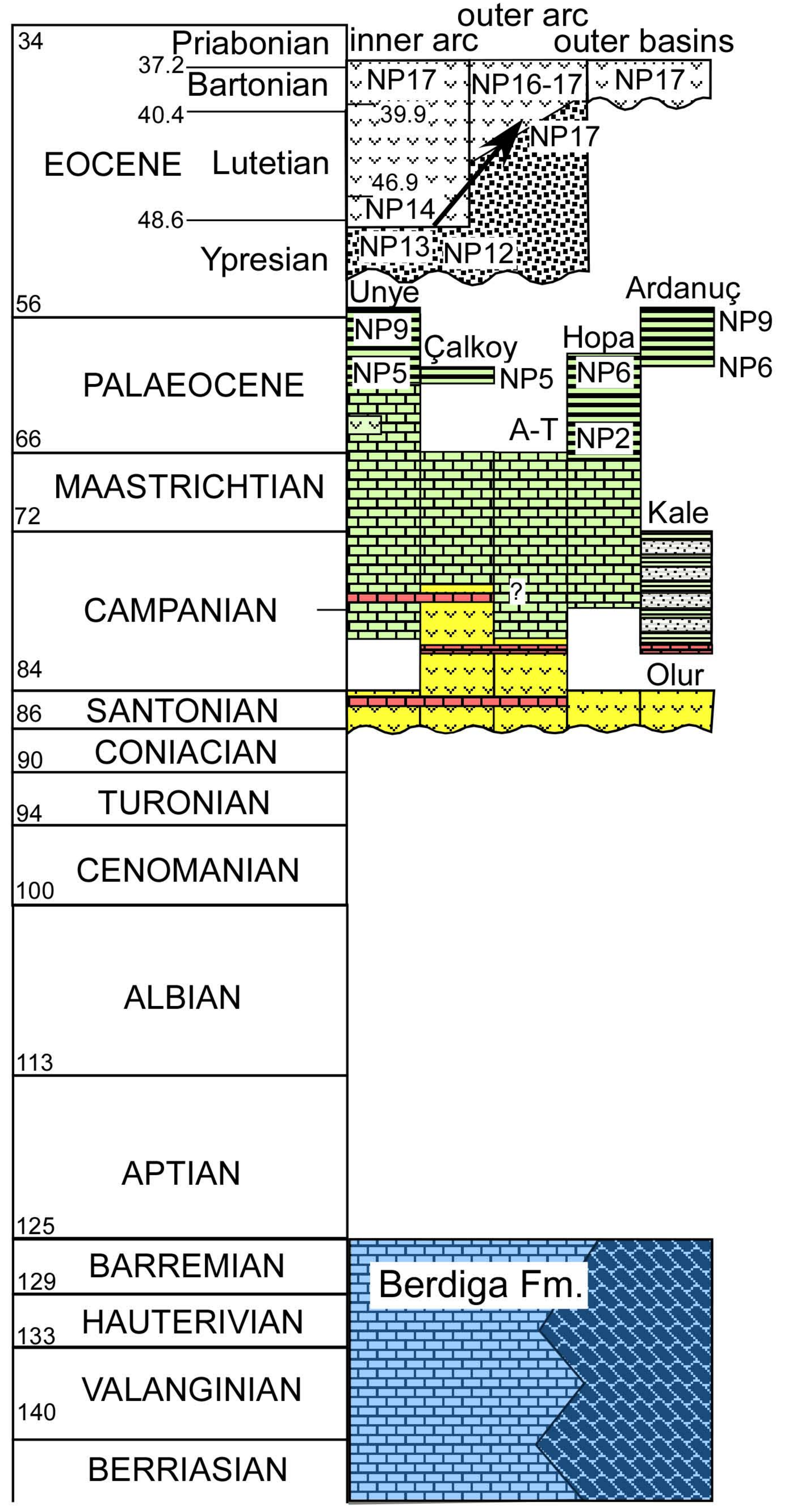




\section{Kale (Gümüshane)}

Alibaba Fm. (Yilmaz, 2002)

$>400 \mathrm{~m}$ volcanogenic sequence (volcanoclastic sandstones, lavas, agglomerates...)

$44.7 \pm 0.8 \mathrm{Ma}$ non-adakitic lavas (Eyuboglu et al.,2013)

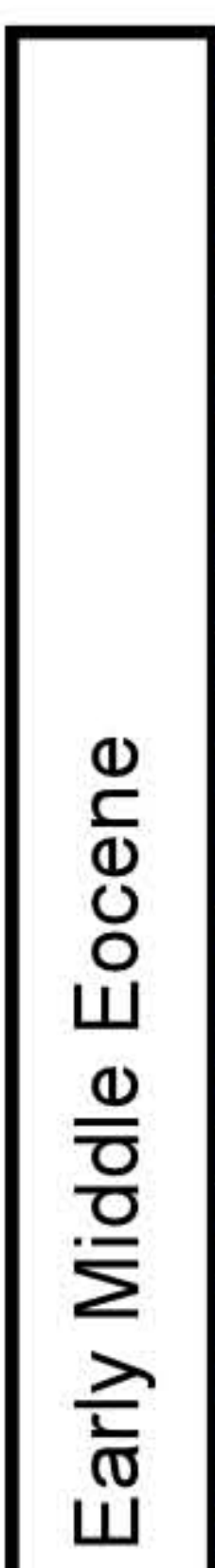

$\longleftarrow$ Middle Eocene NP16? (S90)

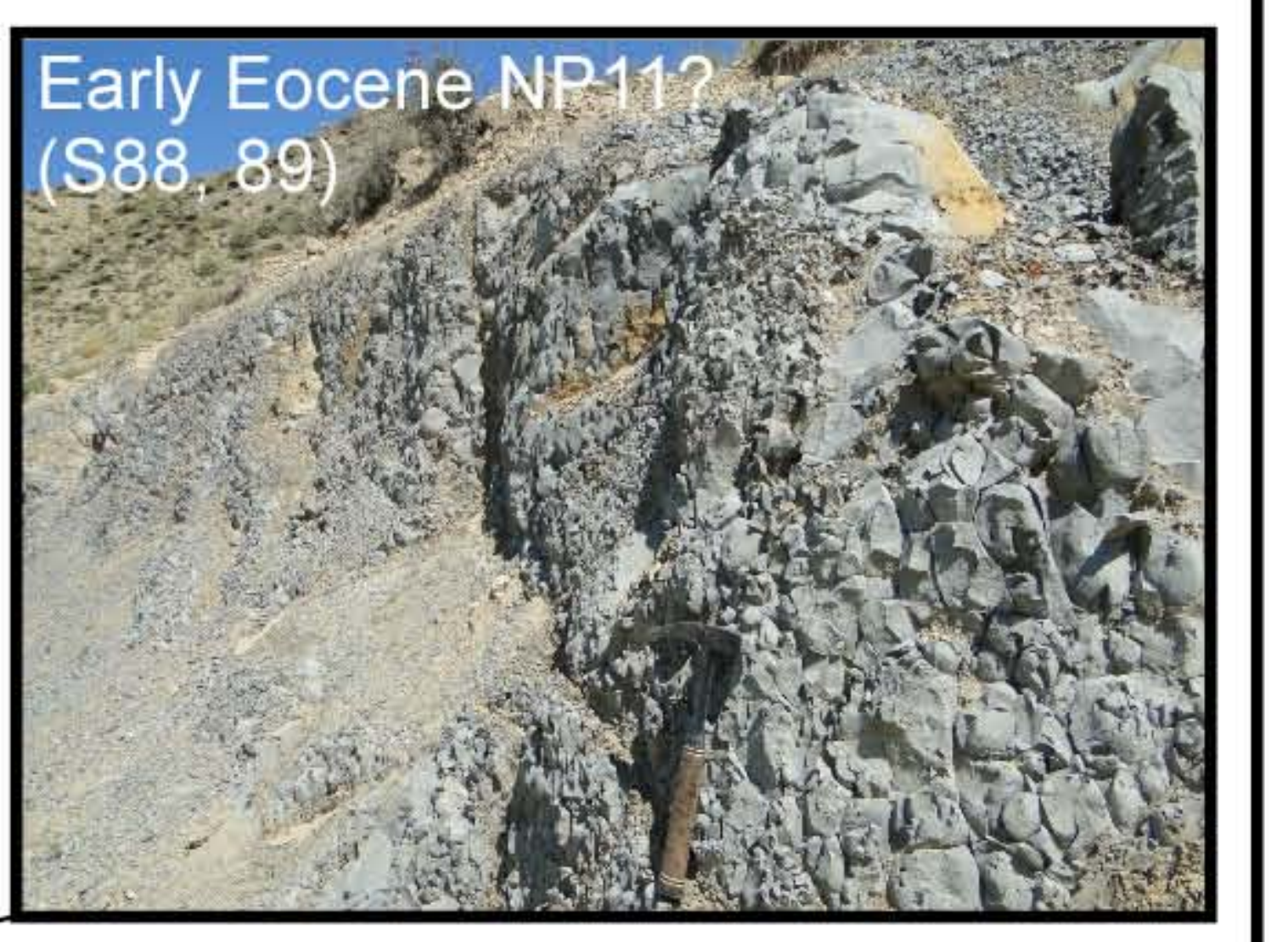
local 48-50 Ma adakitic lavas (Karsli et al., 2010;

Eyuboglu et al.,2013)

$\sim 100 \mathrm{~m}$ blue marls

Kermutdere Fm. (Tokel, 1972)

$>150$ m green siliciclastic turbidites

Campanian Coniacian-Santonian
Eren and Tasli (2002)

Berdiga Fm.

Berriasian-Early Aptian

Eren and Tasli (2002)

$\sim 300$ m platform carbonates

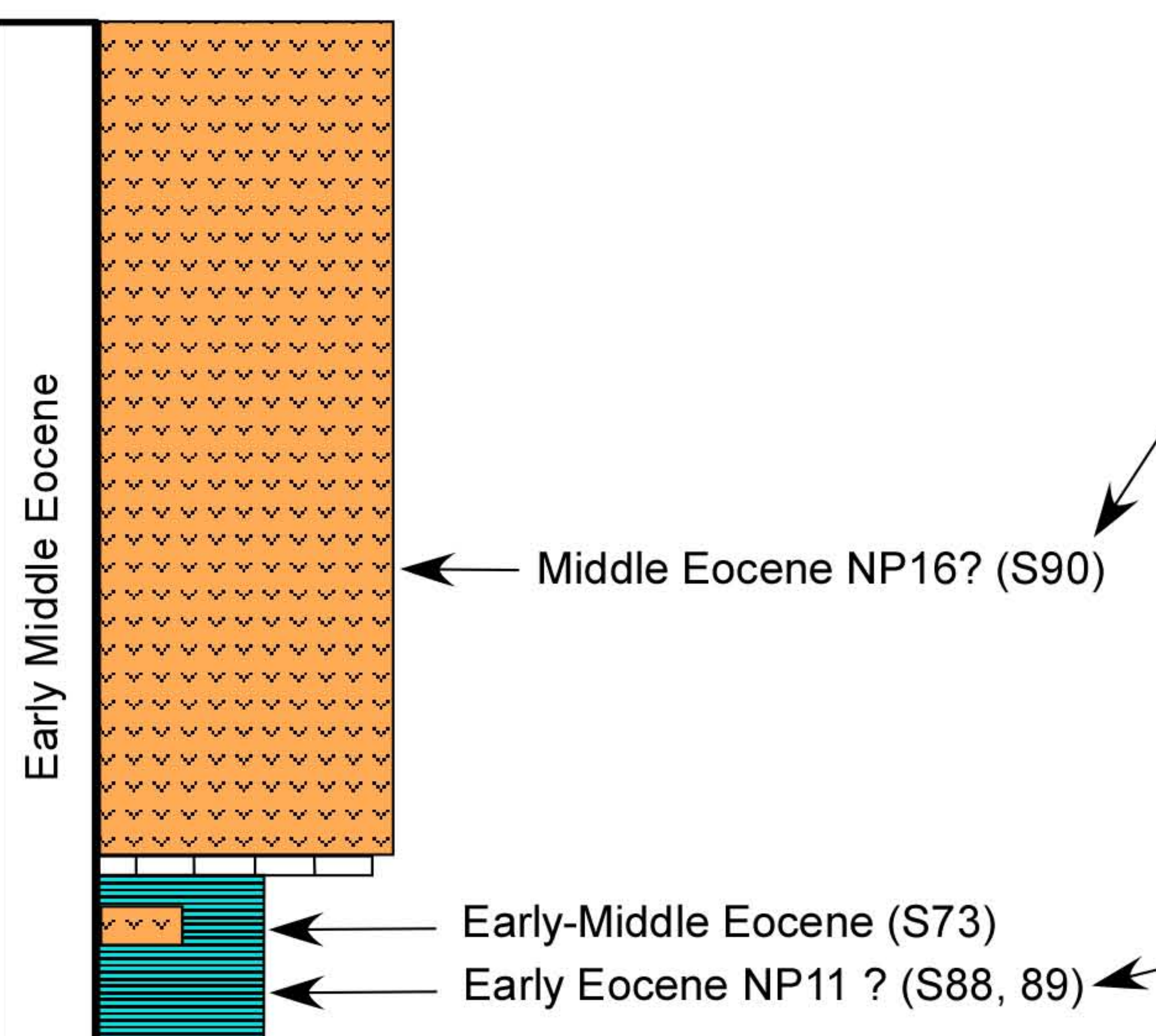

Late Campanian (S98 to 103)

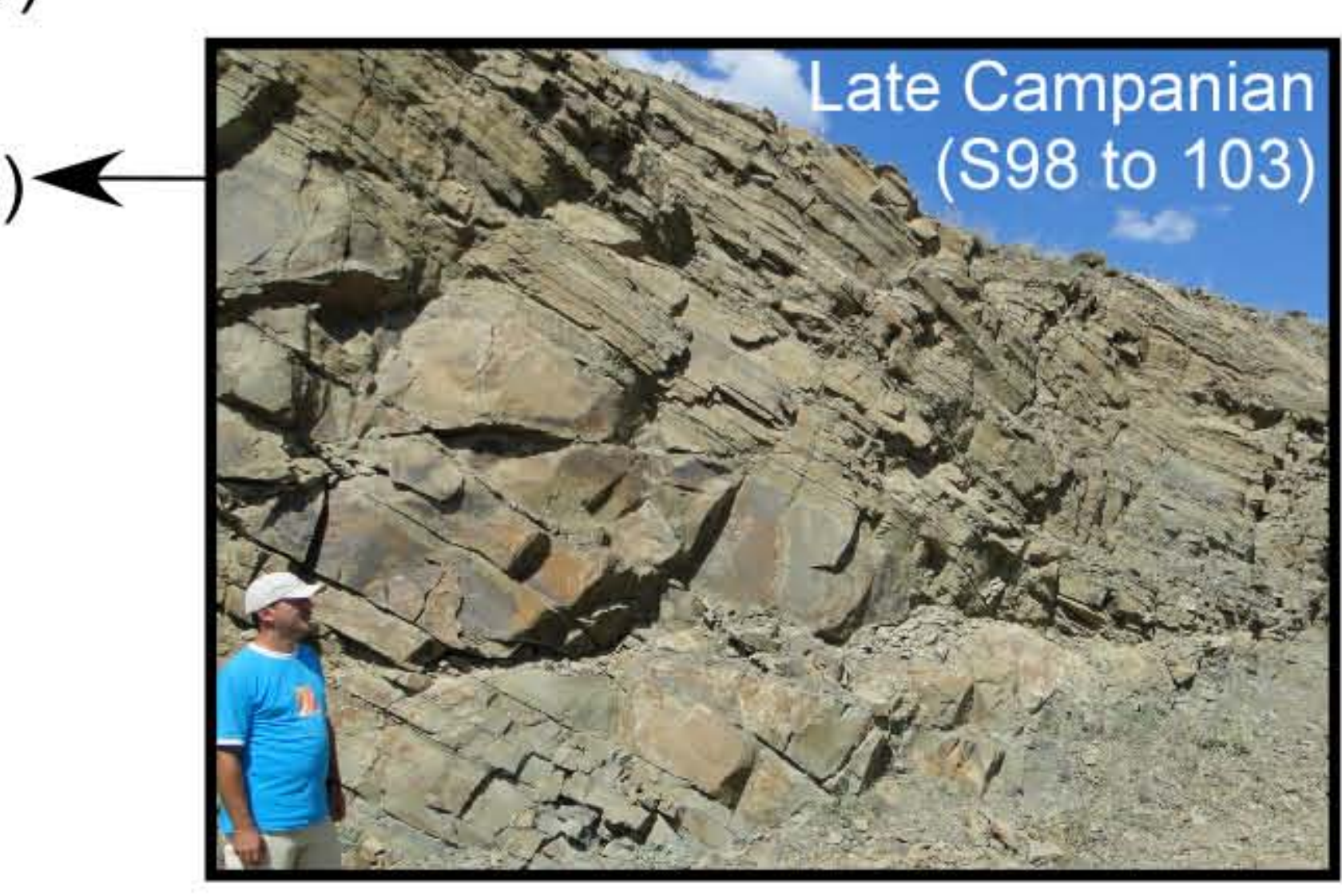

Early Campanian (S95)

Early Campanian (S93)

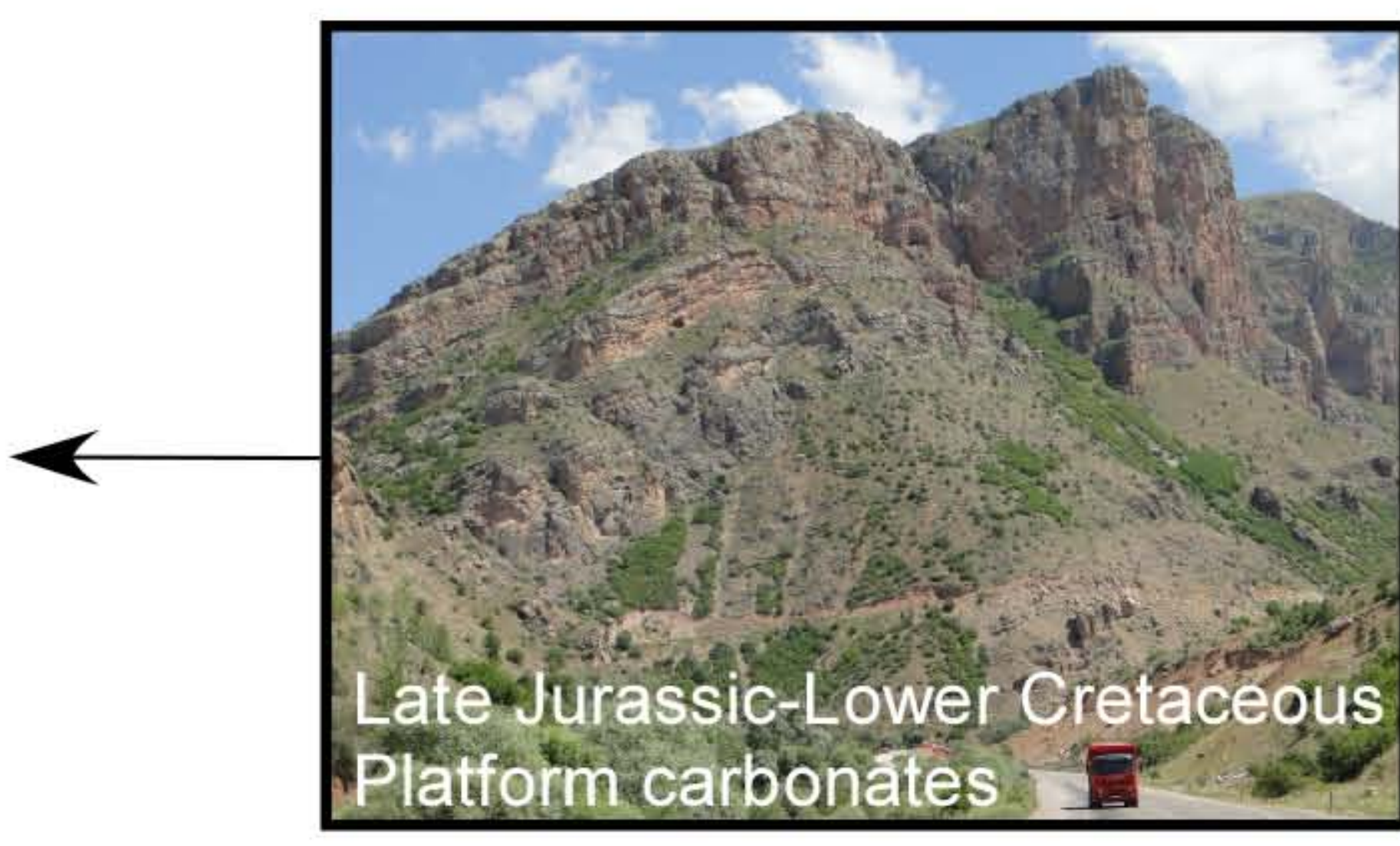




\section{Akrasu-Trabzon}

Kabaköy Fm.

(Sofracioglu and Kandemir (2013) basalts andesites, pyroclatics,

sandstones, marls

Tonya Fm. Late Campanian

(Sofracioglu and Kandemir (2013)

$>30 \mathrm{~m}$ white calciturbidites

Upper Cretacous

volcanic and

volcanic-sedimentary

$\begin{array}{ll}\overparen{N} & \text { sequence (andesite, } \\ \text { ลิ } & \text { baslt, sandstone, marl) }\end{array}$

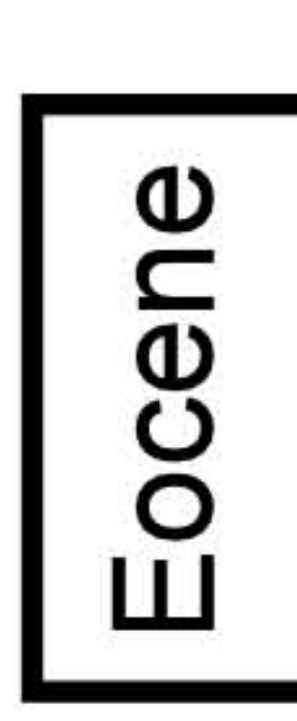

J
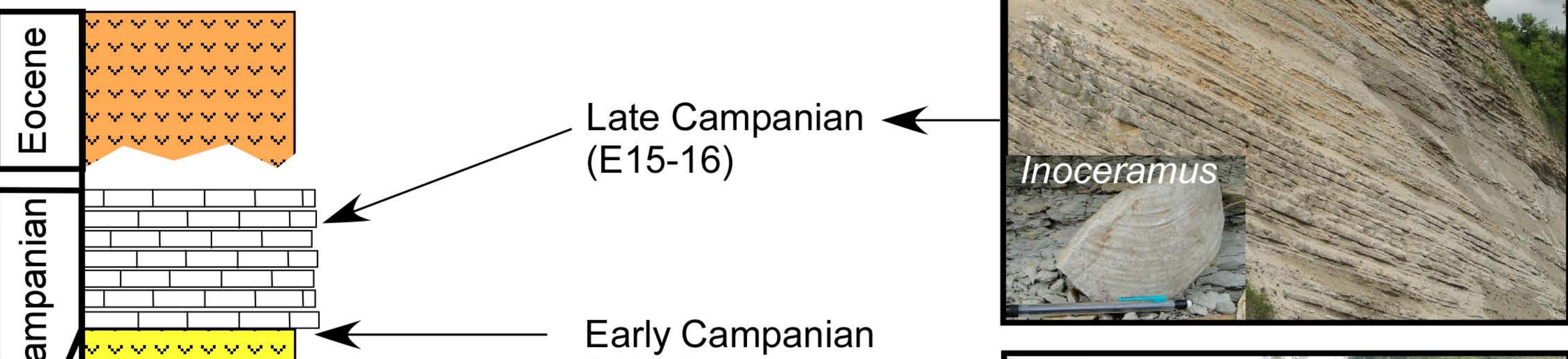

(E136)
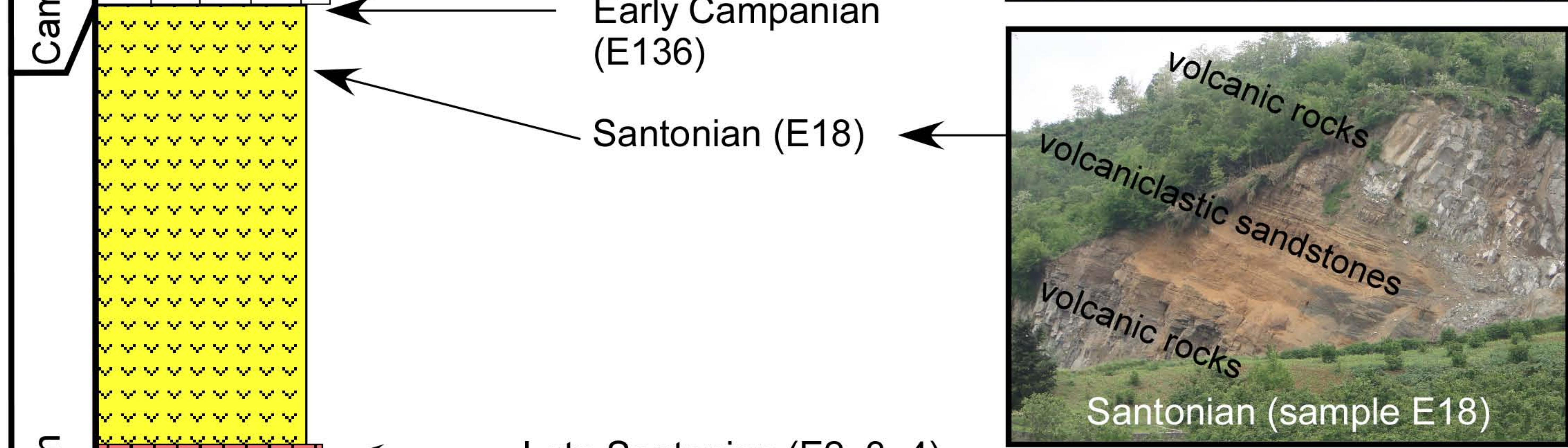

$>5 \mathrm{~m}$ thick

red pelagic limestone

Berdiga Fm.

Upper Jurassic-Lower Cret.

(Pelin, 1977)

胥

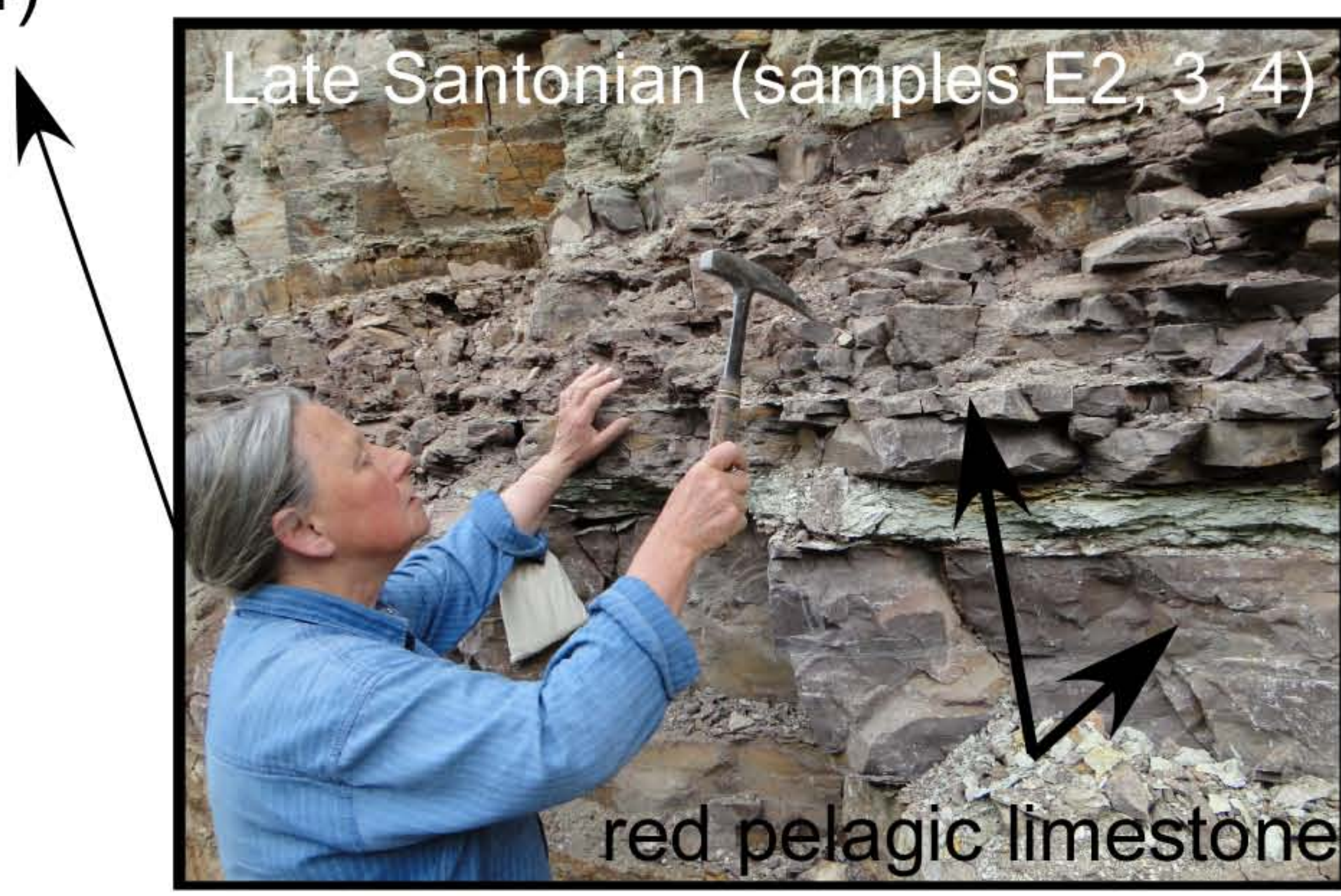

$\frac{\text { 을 }}{\frac{0}{c}}$

(

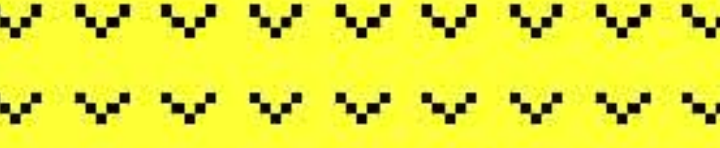

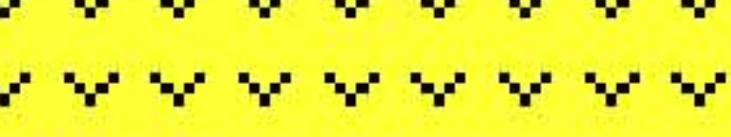

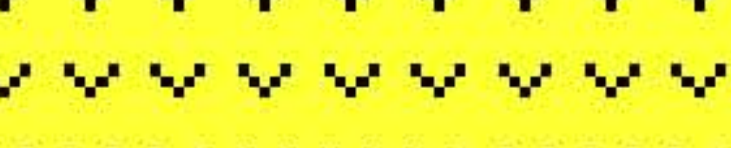

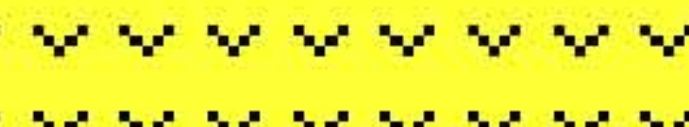

Q

(n)

(1)

(1)

(1)

(1)

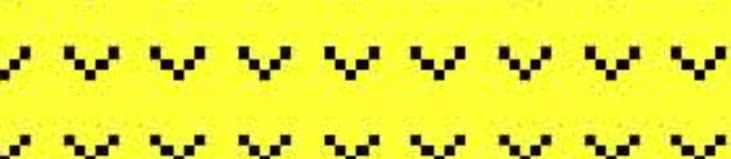

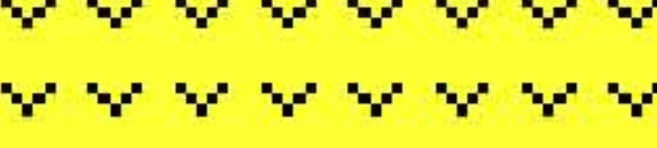

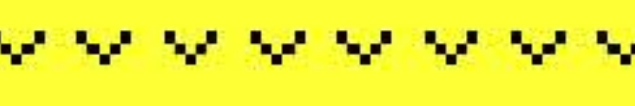

(

(1)

$\longleftarrow$ Late Santonian (E10-12)

Upper Jurassic Lower Cretaceous

limestone, dolomite 


\section{Çalkoy (Trabzon)}

\section{Foldere Fm. \\ Lutetian (Kormaz, 1993) \\ $>400 \mathrm{~m}$ volcanogenic sequence (andesite, basalt, pyroclastics, sedimentary intercalations)}

$>20$ m calcareous sandstone Tonya Fm.

Maastrichtian-Danian (Kormaz, 1993)

Maastrichtian-Thanetian (Inan et al., 1999)

$100 \mathrm{~m}$ white limestone $10 \mathrm{~m}$ grey marl $\sim 30 \mathrm{~m}$ white tuff

$>15 \mathrm{~m}$ red pelagic limestone with volcaniclastic intercalations $>40$ m white tuff

$2 \mathrm{~m}$ red pelagic limestone Düzköy Fm. white tuff Campanian-Maastrichtian (Kormaz, 1993)

$>80 \mathrm{~m}$ volcanogenic sequence (andesite, basalts, pyroclastics) pillow lava

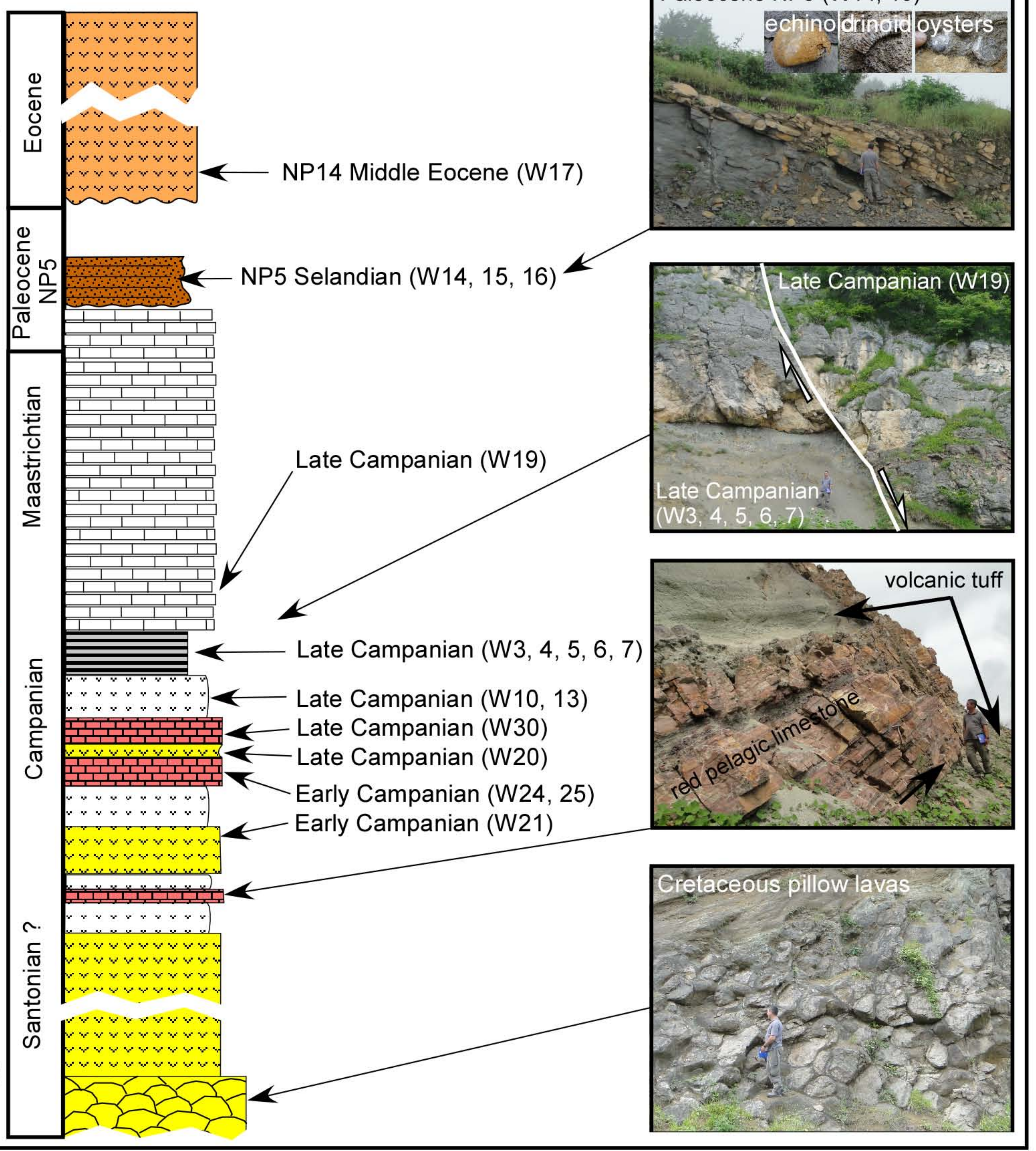




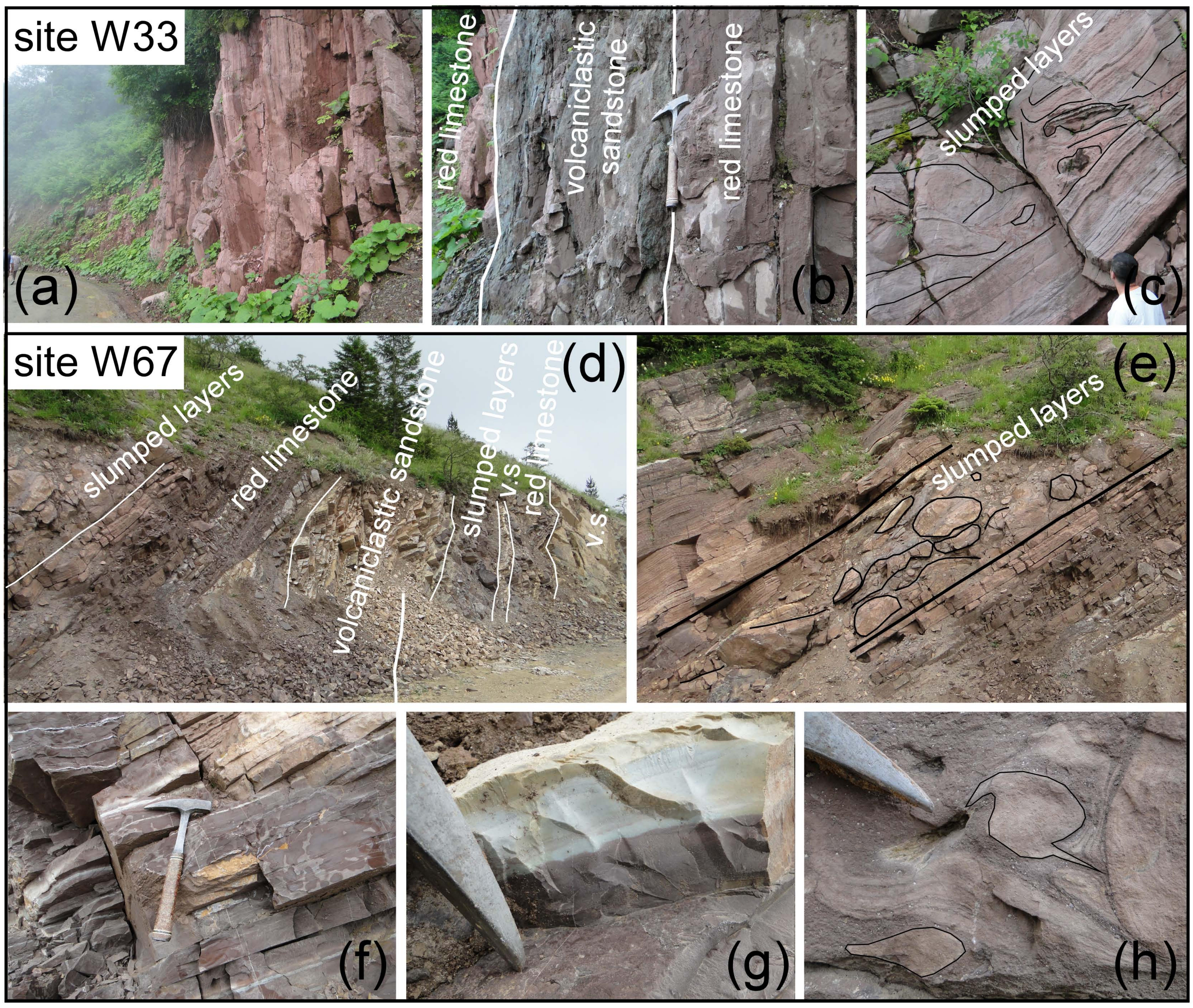




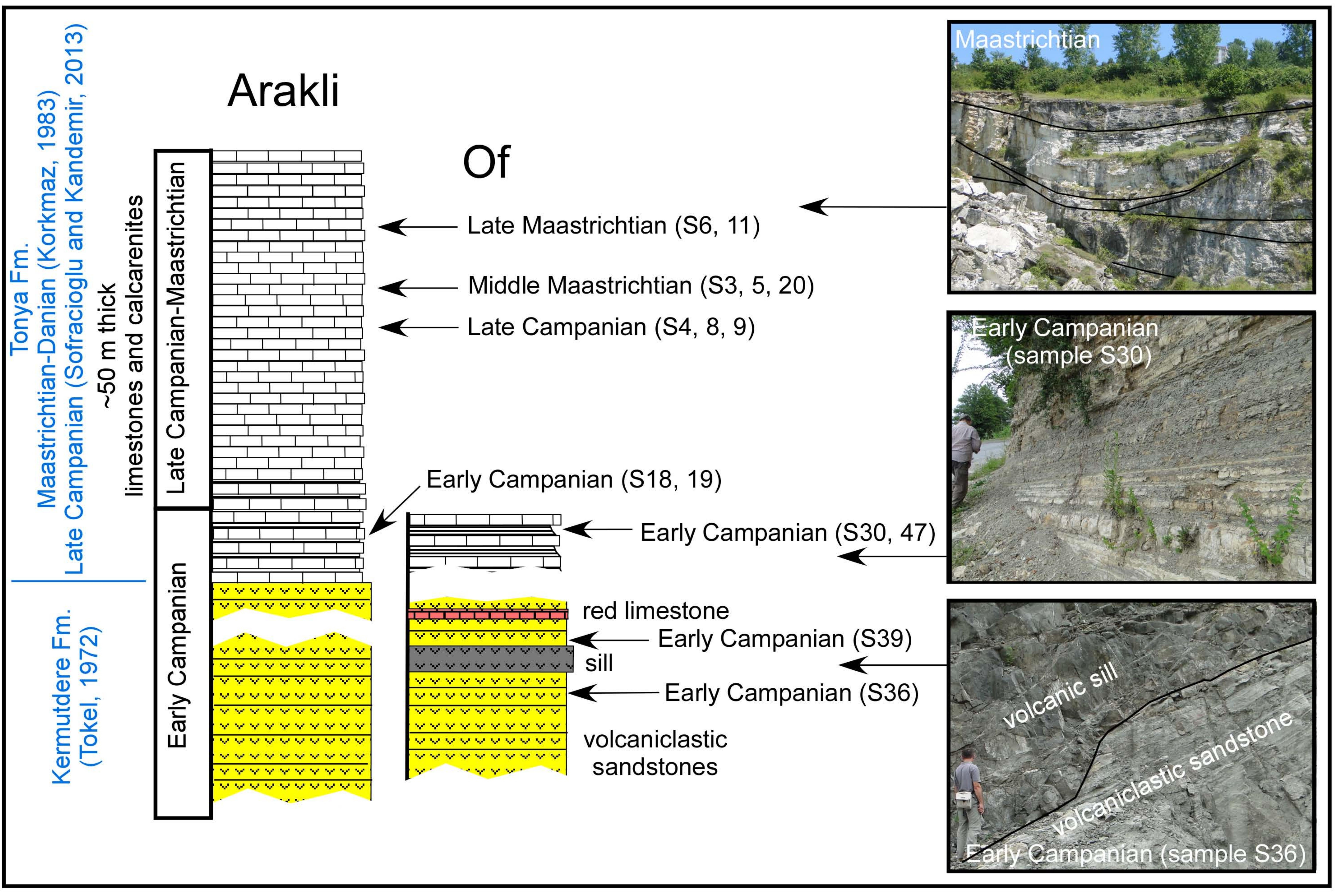




\section{Hopa-Borçka \\ Hopa North}

$\sim 700 \mathrm{~m}$ thick volcanic and volcaniclastic rocks

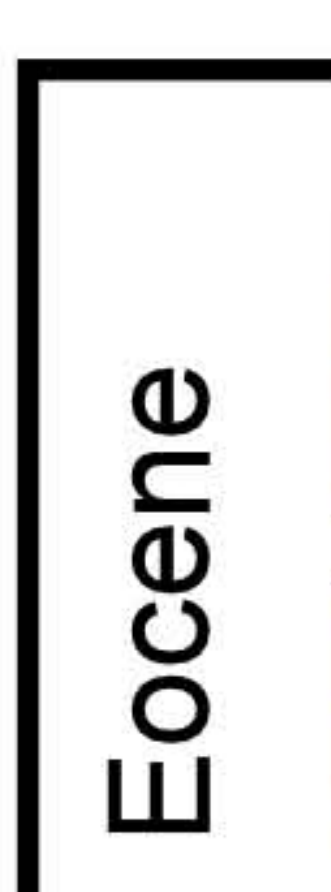

Aydinçakir and Sen, 2013 roroser (1)

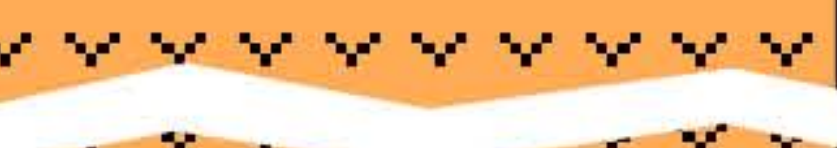

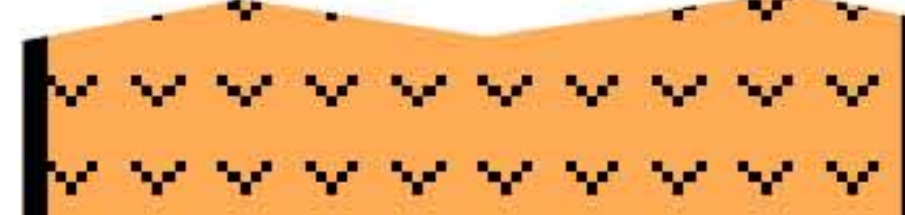
(

$46.9 \pm 0.1 \mathrm{Ma}$ NP17 $(E 23,24)$

$>30 \mathrm{~m}$ thick red marls

Tonya Fm. $\sim 200 \mathrm{~m}$ thick limestones, with slumped layers and normal faults

Kermutdere Fm. (Tokel, 1972)

volcaniclastic sandstones and volcanic rocks

pillow lava
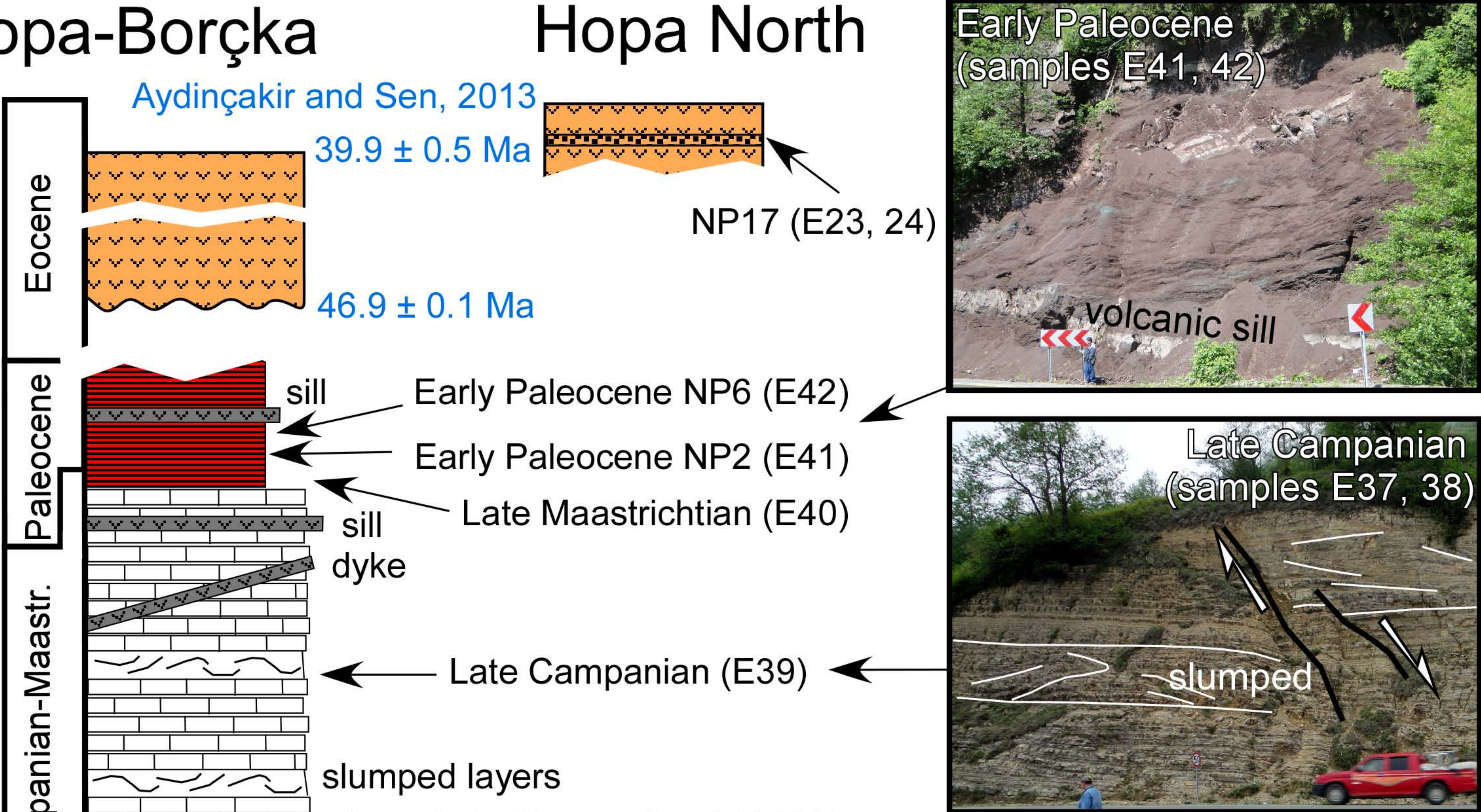

E
$\mathbb{N}$
0
$\stackrel{D}{\sigma}$

$\longleftarrow$ Late Campanian $(E 37,38)$
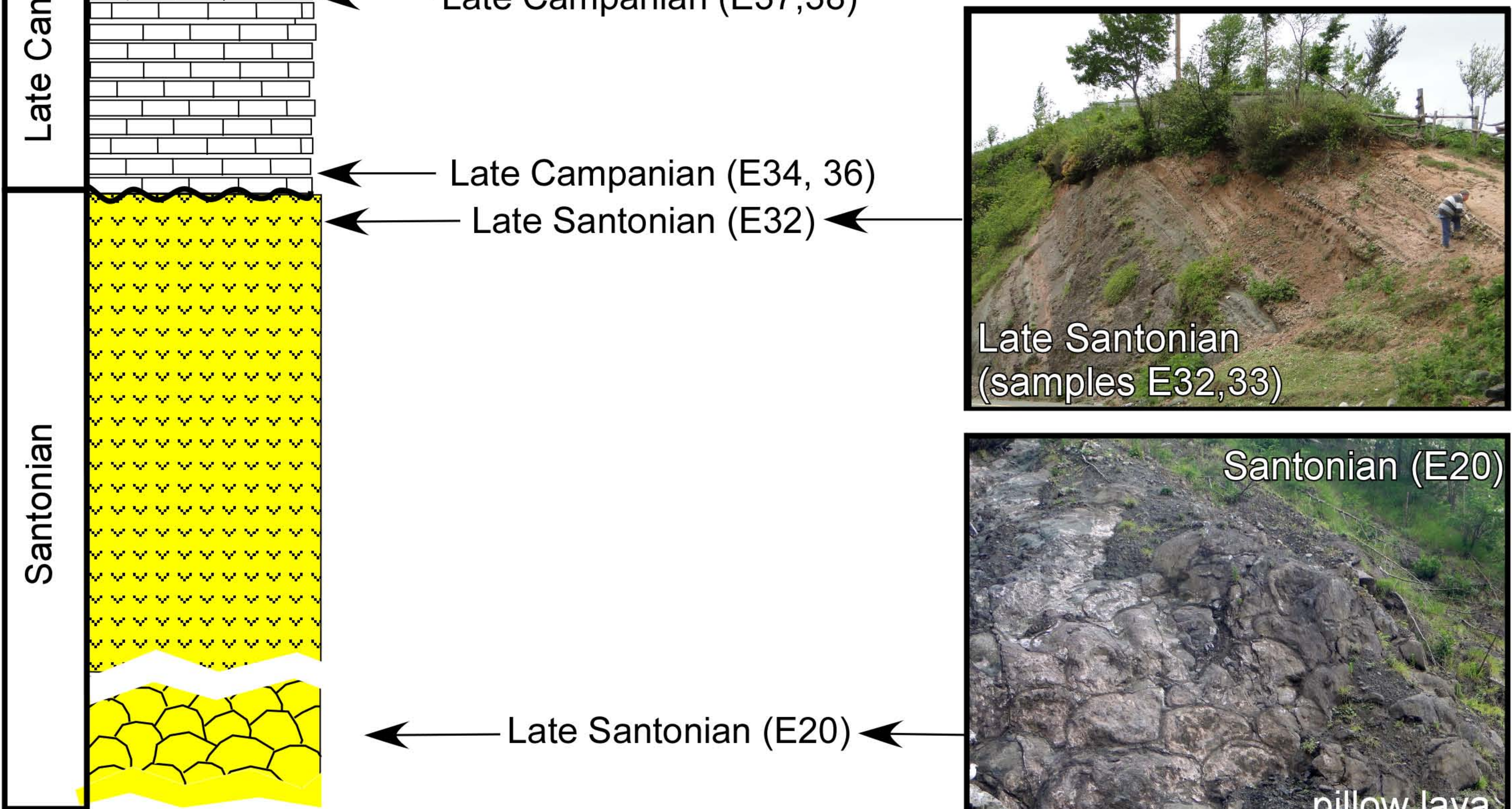

$\longleftarrow$ Late Campanian (E34, 36)

$\longleftarrow$ Late Santonian (E32)

$\checkmark \checkmark \checkmark \checkmark \checkmark \checkmark \checkmark \checkmark$

(r) $\checkmark \checkmark \checkmark \checkmark \checkmark \checkmark \checkmark$

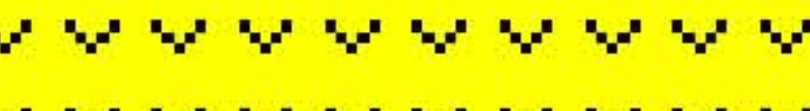
Q $\checkmark \checkmark \checkmark \checkmark \checkmark \checkmark \checkmark$

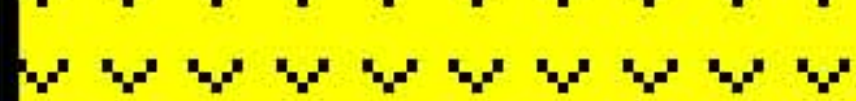
(samples E32,33)

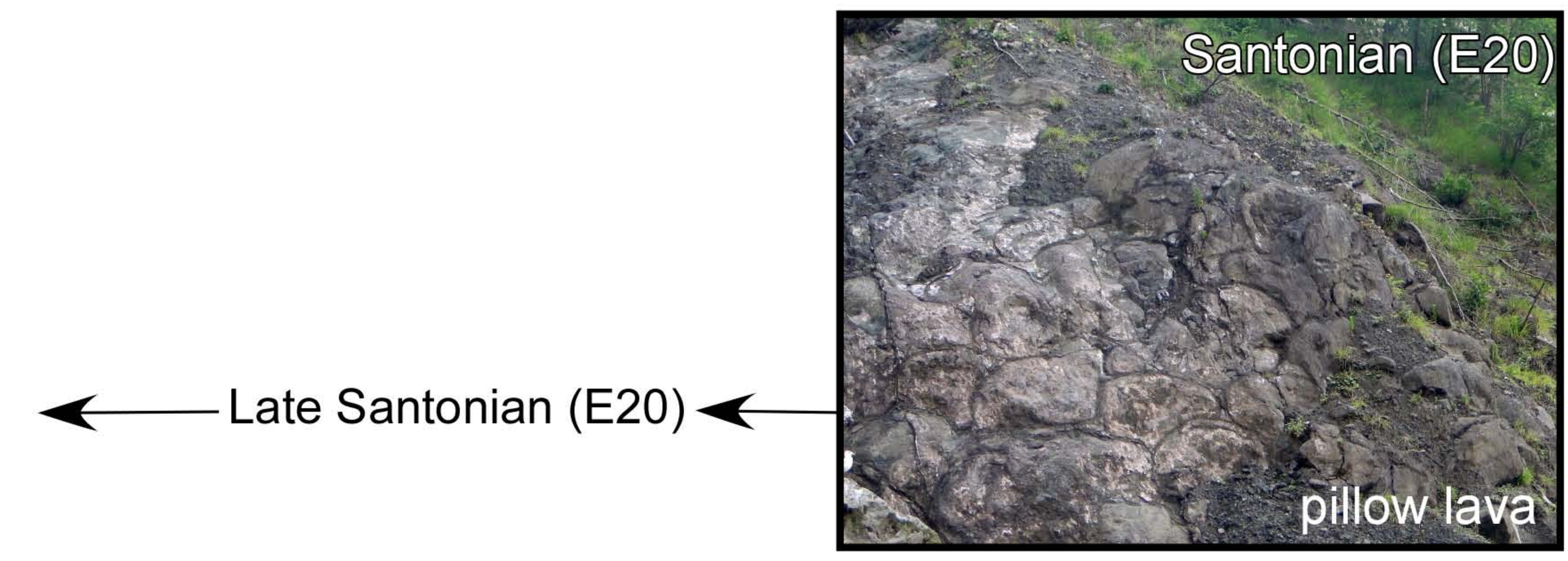


Campanian Paleocene

Santonian-

Lower Campanian? plutonic rocks 


\section{Ardanuç basin}

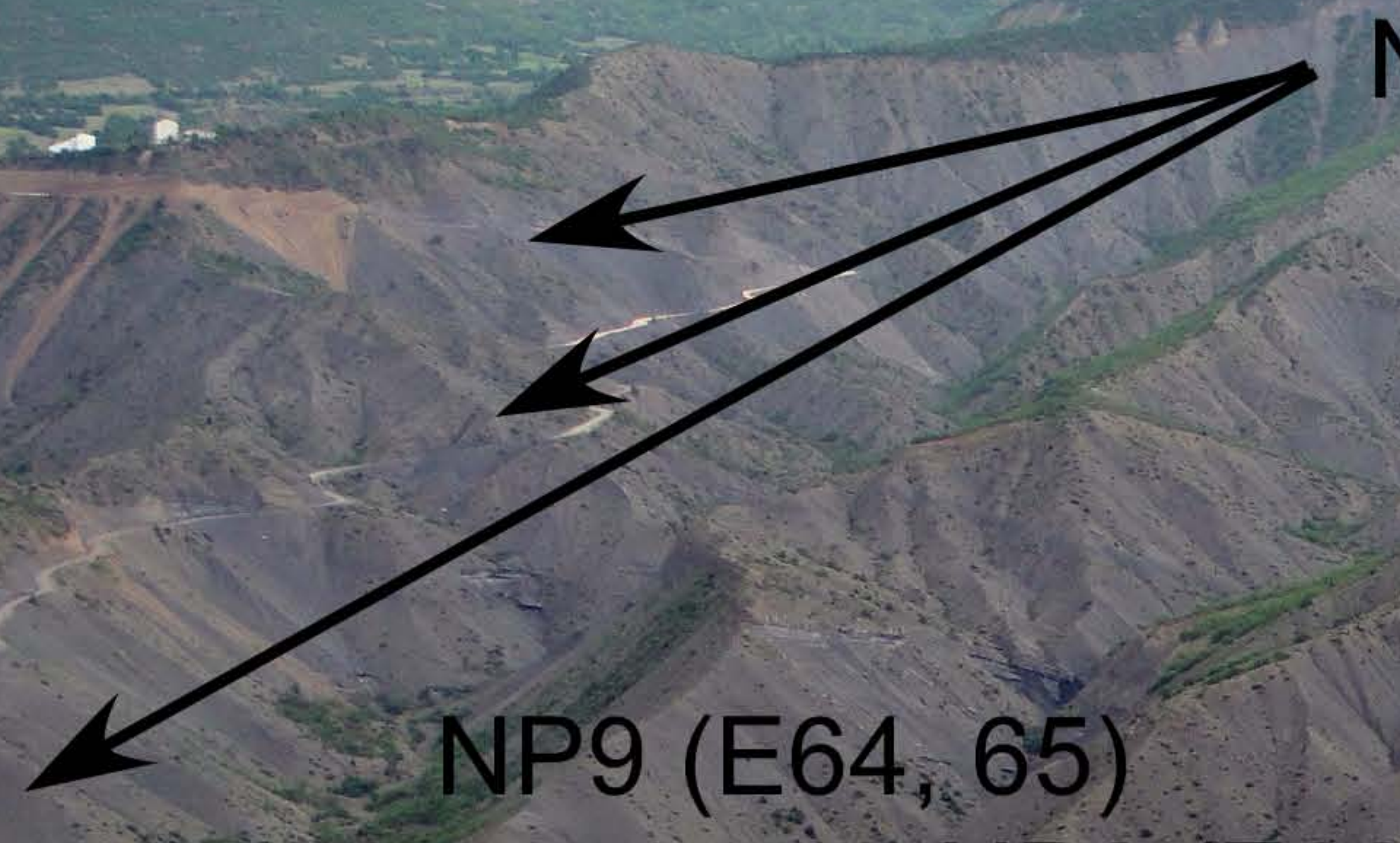

\section{NP9 (E51, 55, 57-62)}

\section{NP9 (E48)}

wher $x+x^{2}=$

NP6 $(E 66)=$

atilte

2.

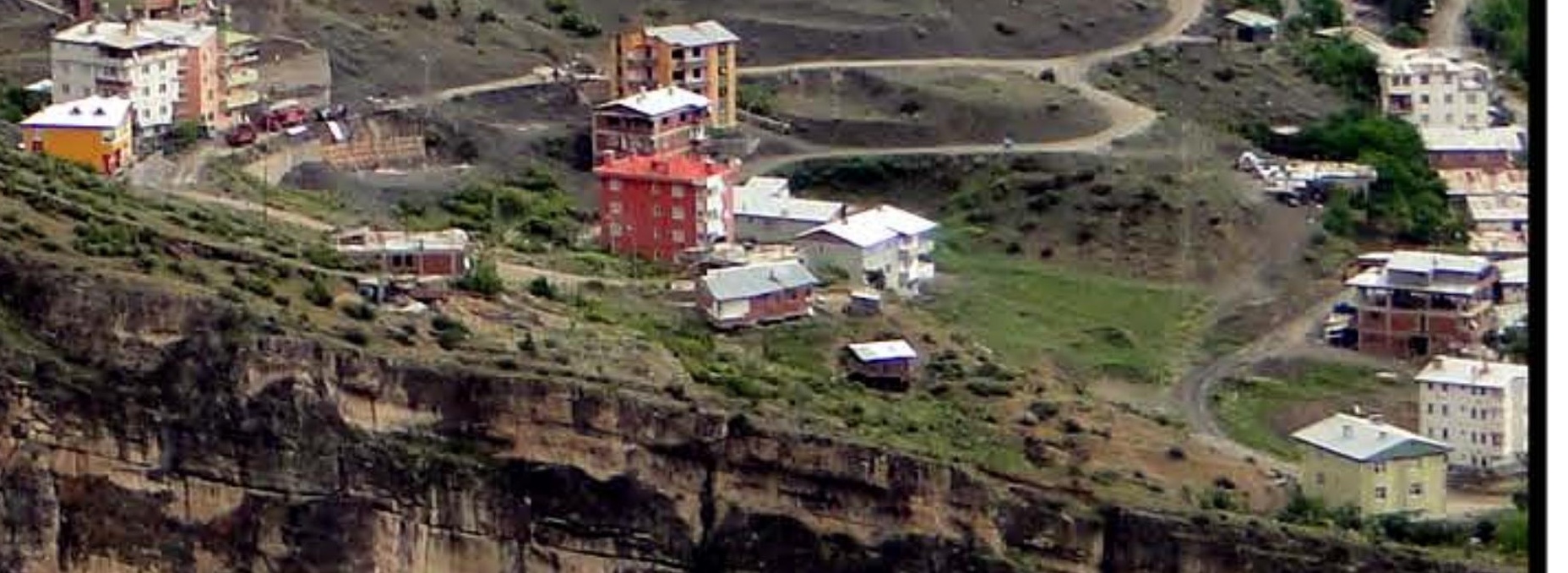
5. - limestone
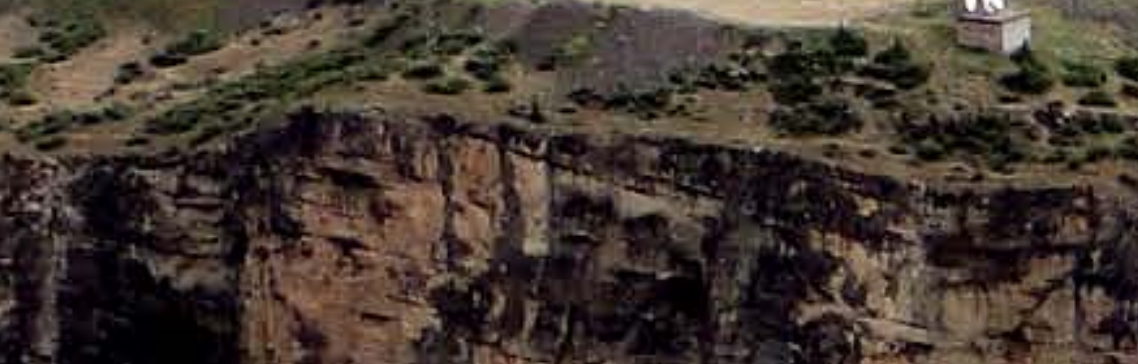

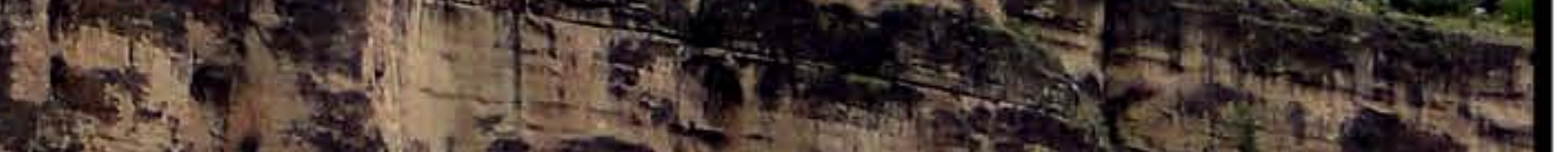

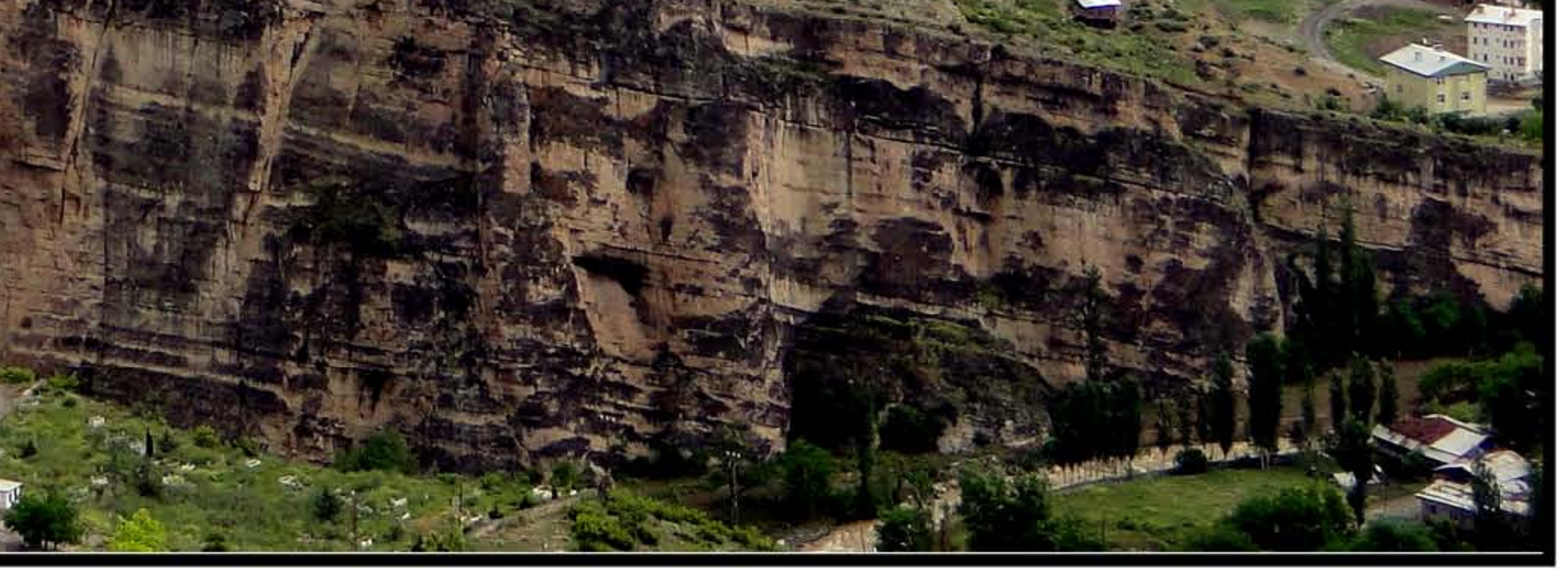






